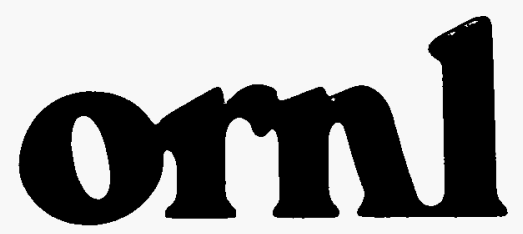

OAK RIDGE NATIONAL LABORATORY

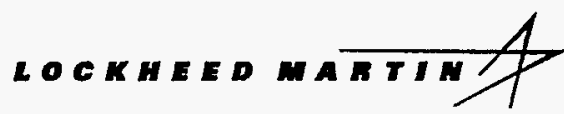

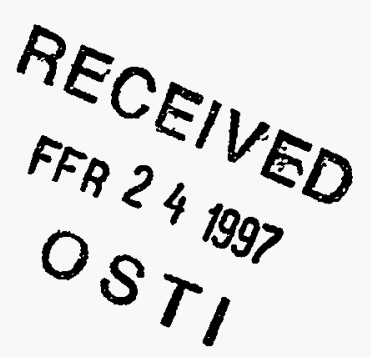

\section{Ancillary-Service Details: Dynamic Scheduling}

Eric Hirst

Brendan Kirby 
This report has been reproduced directly from the best available copy.

Available to DOE and DOE contractors from the Office of Scientific and Technical Information, P.O. Box 62, Oak Ridge, TN 37831; prices available from (423) 576-8401, FTS 626-8401.

Available to the public from the National Technical Information Service, U.S. Department of Commerce, 5285 Port Royal Rd., Springfield, VA 22161.

This report was prepared as an account of work sponsored by an agency of the United States Government. Neither the United States Government nor any agency thereof, nor any of their employees, makes any warranty, express or implied, or assumes any legal liability or responsibility for the accuracy, completeness, or usefulness of any information, apparatus, product, or process dis. clased, or represents that its use would not infringe privately owned rights. Reference herein to any specific commercial product, process, or service by trade name, trademark, manufacturer, or otherwise, does not necessarily constitute or imply its endorsement, recommendation, or favoring by the United States Govemment or any agency thereof. The views and opinions of authors expressed herein do not necessarily state or reflect those of the United States Government or any agency thereof. 


\section{DISCLAIMER}

Portions of this document may be illegible electronic image products. Images are produced from the best available original document. 
ORNL/CON-438

ENERGY DIVISION

\title{
ANCILLARY-SERVICE DETAILS: DYNAMIC SCHEDULING
}

\author{
ERIC HIRST and BRENDAN KIRBY
}

January 1997

\author{
Sponsored by \\ Detroit Edison Company \\ Detroit, Michigan \\ and \\ Office of Utility Technologies \\ Office of Energy Efficiency and Renewable Energy \\ U.S. Department of Energy
}

OAK RIDGE NATIONAL LABORATORY

Oak Ridge, Tennessee 37831

managed by

LOCKHEED MARTIN ENERGY RESEARCH CORPORATION

for the

U.S. DEPARTMENT OF ENERGY

under contract No. DE-AC05-96OR22464 


\section{CONTENTS}

Page

SUMMARY $\ldots \ldots \ldots \ldots \ldots \ldots \ldots \ldots \ldots \ldots \ldots \ldots \ldots \ldots \ldots \ldots \ldots$

LIST OF ACRONYMS $\ldots \ldots \ldots \ldots \ldots \ldots \ldots \ldots \ldots \ldots \ldots \ldots \ldots \ldots \ldots$

1. INTRODUCTION $\ldots \ldots \ldots \ldots \ldots \ldots \ldots \ldots \ldots \ldots \ldots \ldots \ldots \ldots \ldots \ldots \ldots \ldots$

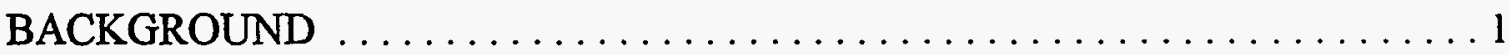

PURPOSE AND CONDUCT OF THIS PROJECT $\ldots \ldots \ldots \ldots \ldots \ldots \ldots \ldots$

2. DYNAMIC-SCHEDULING DETAILS $\ldots \ldots \ldots \ldots \ldots \ldots \ldots \ldots \ldots$

3. REASONS TO USE DYNAMIC SCHEDULING $\ldots \ldots \ldots \ldots \ldots \ldots \ldots \ldots$

4. EXAMPLES OF DYNAMIC SCHEDULING $\ldots \ldots \ldots \ldots \ldots \ldots \ldots \ldots \ldots \ldots$

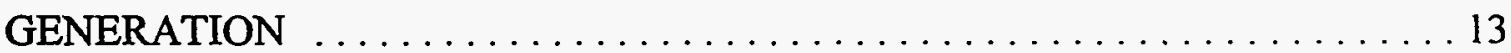

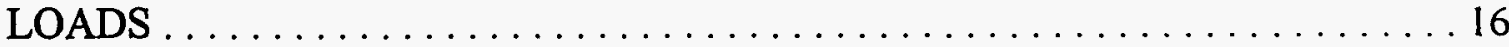

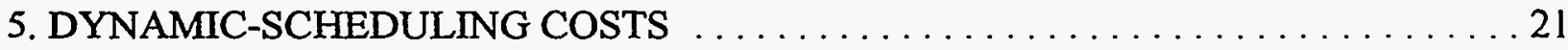

6. RELATIONSHIP TO ANCILLARY AND OTHER GRID SERVICES . . . . . . . 23

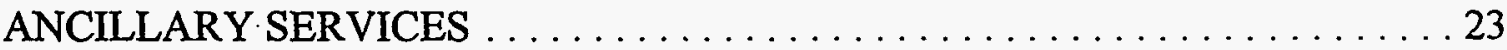

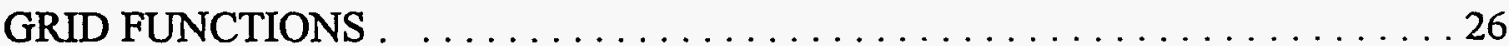

7. NEED FOR ADDITIONAL WORK . . . . . . . . . . . . . . . . . 29

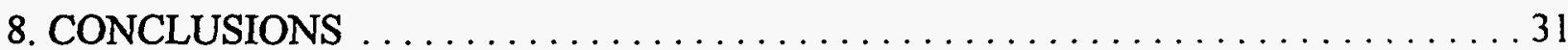

ACKNOWLEDGMENTS $\ldots \ldots \ldots \ldots \ldots \ldots \ldots \ldots \ldots \ldots \ldots \ldots \ldots \ldots \ldots \ldots$

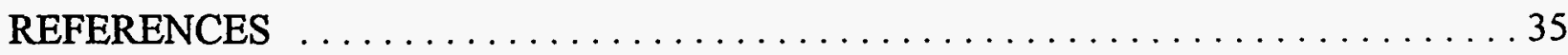




\section{SUMMARY}

Dynamic scheduling is the electronic transfer from one control area to another of the time-varying electricity consumption associated with a load or the time-varying electricity production associated with a generator. Although electric utilities have been using this technique for at least two decades, its use is growing in popularity and importance. This growth is a consequence of the major changes under way in U.S. bulk-power markets, in particular efforts to unbundle generation from transmission and to increase competition among generation providers.

Dynamic scheduling can promote competition and increase choices. It allows consumers to purchase certain services from entities outside their physical-host control area and it allows generators to sell certain services to entities other than their physical host. These services include regulation (following minute-to-minute variations in load) and operating reserves, among others. Such an increase in the number of possible suppliers and customers should encourage innovation and reduce the costs and prices of providing electricity services.

We identified many current examples in which loads, generation, or both are dynamically scheduled from one control area to another. The Central Arizona Project is perhaps the most interesting example uncovered in this study because it involves the simultaneous scheduling of loads and generation. The Project brings Colorado River water to the areas around Phoenix and Tucson in Arizona; it includes 15 major pumping stations with a load of about 550 MW, all in the control area of the Western Area Power Administration. WAPA aggregates these loads and sends the aggregate signal to the Salt River Project control center (in Phoenix). SRP meets the Project's load with output from the coal-fired Navajo plant (in Page). The Navajo plant, however, is located in the Arizona Public Service control area, so APS schedules the plant's output across its transmission system on behalf of SRP and delivers the power to the WAPA system. APS is the physical host for the power plant, and SRP is the electronic host. WAPA is the physical host for the Project load, and SRP is the electronic host. The successful operation of this complicated dynamic schedule shows the feasibility, flexibility, and value of dynamic scheduling.

We obtained limited data on the initial and ongoing costs of dynamic scheduling. These data allowed us to assess the approximate costs of dynamic scheduling relative to those of transmission service and transmission losses. As an example, consider a situation in which a $100-\mathrm{MW}$ load, measured at five metering points, is being dynamically scheduled. The total cost of dynamic scheduling would be $0.23 \mathrm{mill} / \mathrm{kWh}$, much less than the cost of generation (which might be 25 mills $/ \mathrm{kWh}$ ). The cost of transmission service and losses (3.2 and $0.7 \mathrm{mills} / \mathrm{kWh}$ ), 
however, would increase the total cost of dynamic scheduling by a factor of almost 20 , but it would still be much less than the cost of generation.

Although dynamic scheduling can be used to transfer many electricity services from one control area to another, there are limits to its applications. Certain services, especially voltage support and black-start capability, are inherently local and cannot easily be moved across control areas. In addition, questions remain about how dynamic scheduling will work when there are many more such transactions then there are today. These questions concern metering complexity, metering and telemetry failures, metering and computer errors, and possible confusion over responsibilities during emergency conditions. In particular, the industry needs to develop procedures to implement dynamic scheduling so that bulk-system reliability is not impaired.

Dynamic scheduling is a reality in today's electricity industry. And competitive forces in bulk-power markets will likely lead to substantial increases in its use. 


\section{LIST OF ACRONYMS}

ACE

AGC

APS

CA

DS

EMS

ERCOT

FERC

HL\&P

IPP

LCRA

NERC

$\mathrm{OE}$

OTP

SRP

TNP

WAPA
Area-control error

Automatic generation control

Arizona Public Service Company

Control area

Dynamic scheduling

Energy-management system

Electric Reliability Council of Texas

Federal Energy Regulatory Commission

Houston Lighting \& Power Company

Independent power producer

Lower Colorado River Authority

North American Electric Reliability Council

Ohio Edison Company

Otter Tail Power Company

Salt River Project

Texas-New Mexico Power Company

Western Area Power Administration 


\section{INTRODUCTION}

\section{BACKGROUND}

As the U.S. electricity industry restructures, various services that were formerly provided by the vertically integrated utility as part of a bundled package are now being disaggregated and offered separately. This unbundling is leading to the redefinition of existing services and to the creation of new services.

This report deals with one such service, often called dynamic scheduling (DS) and sometimes called remote control-area operation. DS refers to the electronic transfer of a load or generator (more precisely, the time-varying electricity consumption associated with a load or the time-varying electricity production associated with a generator) from one control area to another." To illustrate, load L1 in Fig. 1 is dynamically scheduled from its physical host, control area $\mathrm{A}$, to control area $\mathrm{C}$, its electronic host. In essence, DS electronically removes the load from $\mathrm{A}$ and places it in $\mathrm{C}$.

The Federal Energy Regulatory Commission (FERC), in its Order 888 on open-access transmission (U.S. FERC 1996), defined dynamic scheduling as:

the metering, telemetering, computer software, hardware, communications, engineering, and administration required to allow remote generators to follow closely the moment-to-moment variations of a local load. In effect, dynamic scheduling electronically moves load out of the control area in which it is physically located and into another control area.

FERC decided not to require transmission providers to offer this service because "it is a special service that is used only infrequently ... it uses advanced technology and requires a great deal of coordination. ... has unique costs ... making it difficult to post a standard price for the service." Also, FERC did not address dynamic scheduling of generation.

The Electric Reliability Council of Texas (ERCOT 1995) defines a dynamically scheduled load as "A specific load telemetered to both the Load Host and Supply Host and included in the ACE [area-control error] equation as a schedule such that the signal is interpreted by the Load Host as a schedule in and is interpreted by the Supply Host as a

*Electronic transfers could occur within a single control area. For example, the owner of a generator might want to use its output to serve a particular load located elsewhere but within the same control area. 
schedule out." It defines dynamically scheduled generation as "Capacity and energy from a specific source telemetered to both the Generation Host and receiving Control Area and included in the ACE equation as a schedule, such that the signal is interpreted by the receiving Control Area as a schedule in and is interpreted by the Generation Host as a schedule out."

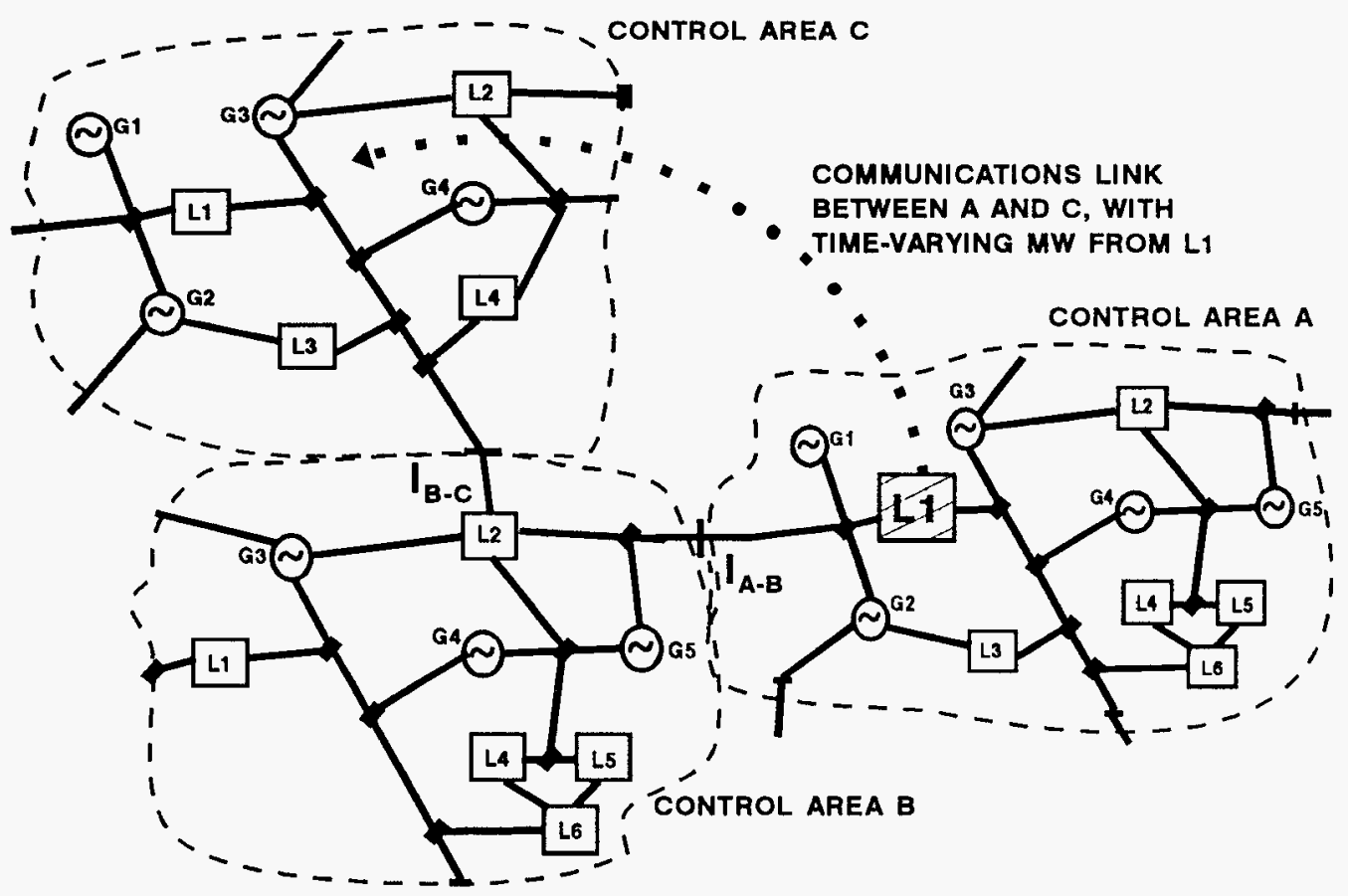

Fig. 1. Schematic of three control areas and the dynamic scheduling of load L1 from its physical host, control area $\mathrm{A}$, to its electronic host, control area $\mathrm{C}$. $L$ refers to a load, $G$ to a generator, and $I$ to an interconnection.

\section{PURPOSE AND CONDUCT OF THIS PROJECT}

We conducted this project to collect and analyze data on utility experiences with DS. The results should help FERC in its future deliberations on the definitions, costs, and prices of ancillary services. These results should also be useful to the North American Electric Reliability Council (NERC) Interconnected Operations Services Working Group (1996), which will issue a report in early 1997 " ... to further define interconnected operations services and how they will be measured in an open access electricity market."

${ }^{*}$ The Load Host is the control area in which the load is located (what we call the physical host). The Supply Host is the control area to which the load is electronically transferred (what we call the electronic host); the Supply Host provides the generation to serve the load that is electronically transferred.

"The Generation Host is the control area in which the generation is physically located. 
Because there is little written literature on DS, we devoted considerable time to discussions with practitioners and analysts within electric utilities and related organizations. (We also searched for and reviewed the relevant literature, primarily papers published by the Institute of Electrical and Electronics Engineers.) Altogether, we discussed some or all of the following issues with individuals from 32 organizations (Table 1):

- alternative definitions and applications of DS

- size (MW and MWh) of loads and generation that are dynamically scheduled

- any differences, conceptual or practical, in dynamically scheduling loads vs generation

any practical differences between DS (which adjusts the ACE equation to incorporate the load or generation as a schedule) and remote control-area load or generation (which adjusts the ACE equation to incorporate the load or generation as a new point of interconnection)

- possible limits on the distance (or the number of intervening control areas) between the control area in which the load is located and the control area providing the regulation and operating-reserve services for that load (or by dynamically scheduled generation)

- possible limits on the number of dynamic schedules that can reasonably be accommodated

- speed of response, reliability, and cost of sensors, telecommunications, computing, and other equipment required to accomplish DS

- indicators of the success of DS [and the metrics used to measure success, such as changes in $\mathrm{ACE}$, changes in meeting the $\mathrm{A} 1$ and $\mathrm{A} 2$ criteria (defined in Chapter 2), or reductions in generating costs]

- contingency actions taken when metering, communications, or computer equipment fails or when transmission outages occur

- cost-causation factors and the costs to dynamically schedule loads and generators.

Chapter 2 provides additional details and examples of the definitions of DS. Chapter 3 explains why DS might be an attractive service that customers and generators, as well as transmission providers, might want to use. Chapter 4 presents some of the many current DS examples that we uncovered in our interviews. Chapter 5 discusses the costs and costeffectiveness of DS. Chapter 6 explains what we believe can and cannot be electronically moved from one control area to another, primarily in terms of the six ancillary services that FERC defined in Order 888. And Chapter 7 discusses the need for additional research on DS. 


\section{Table 1. Entities that provided information for this study on dynamic scheduling}

\section{Investor-owned utilities}

American Electric Power

Arizona Public Service

Commonwealth Edison

Consumers Power

Detroit Edison

Duke Power

Entergy

Houston Lighting \& Power

Montana Power

Ohio Edison

Otter Tail Power

PacifiCorp

Potomac Electric Power

Public Service Electric \& Gas

Puget Power

Southern California Edison

Southern Company

Tampa Electric

Wisconsin Electric

\section{Federal and state utilities}

Bonneville Power Administration

Lower Colorado River Authority

Tennessee Valley Authority

Western Area Power Administration

Cajun Electric Power Cooperative

\section{Public power utilities}

Jacksonville Electric Authority

Orlando Utilities Commission

Wisconsin Public Power Inc. System

Electric Power Research Institute

\section{Regional and national entities}

New England Power Pool

North American Electric Reliability Council

PJM Interconnection Association

Western Systems Coordinating Council 


\section{DYNAMIC-SCHEDULING DETAILS}

To understand the mechanics of dynamic scheduling, one must first understand the concept of a control area and its functions. NERC (1995) defines a control area as: "An electrical system bounded by interconnection (tieline) metering and telemetry. [Each control area] controls its generation directly to maintain its interchange schedule with other control areas and contributes to frequency regulation of the Interconnection." There are four bulk electric networks (interconnections) in North America: Eastern, Western, ERCOT, and Quebec. Within each interconnection, all the generators are synchronized and therefore operate at the same frequency, and electricity flows freely on $\mathrm{AC}$ transmission lines. Electricity flows between the four interconnections are limited and occur only on DC links.

Control areas seek to minimize any adverse effect they might have on other control areas within the interconnection by minimizing their ACE. ACE is the instantaneous difference between actual and scheduled interchange, adjusted to take account of any difference between actual and scheduled frequency in the interconnection."

Each control area maintains some generating units on automatic generation control (AGC) "to continuously balance its generation and interchange schedules to its load." AGC refers to equipment in the control center that automatically computes $A C E$ once every few seconds and, based on the calculated errors, sends signals to individual generating units to increase or decrease output to reduce $\mathrm{ACE}$ to zero. AGC also refers to equipment at individual generators that respond to the control-center AGC signals (Hirst and Kirby 1996).

NERC defines two key control-area performance criteria. The first (Al) requires that, on an instantaneous power basis, the control area be in balance with the rest of the interconnection (i.e., ACE must equal zero) at least once every 10 minutes. The second criterion

* The ACE equation, in slightly simplified form, is: $A C E=\left(I_{A}-I_{S}\right)-10 \beta\left(F_{A}-F_{S}\right)$, where I refers to the algebraic sum of all power (MW) flows on the tielines between an individual control area and its surrounding control areas, $F$ is the interconnection frequency $(\mathrm{Hz}), A$ is actual, $S$ is scheduled, and $\beta$ is the control area's frequency bias $(\mathrm{MW} / 0.1 \mathrm{~Hz})$. The first term shows how well the control area performs in matching its schedules with other control areas (i.e., how well it matches its generation plus net incoming scheduled flows to its loads). The second term is the individual control area's contribution to the interconnection to maintain frequency at its scheduled value (usually $60 \mathrm{~Hz}$ ). Appendix 1A of NERC (1995) shows how the ACE equation is modified for jointly owned generating units using a pseudo-tieline or DS approach, for supplemental regulation service, and for load or generation transfer by telemetry. 
(A2) requires that the control area's energy imbalance (average ACE) be within a certain limit called $\mathrm{L}_{\mathrm{d}}$ (roughly 0.2 to $0.5 \%$ of peak demand) every 10 minutes.

The electronic transfer of a load (or of generation) can be implemented in one of two ways. The first, called dynamic scheduling, was defined above. The second, called remote control-area load or the creation of a pseudo-tieline, was defined by ERCOT (1995) as "A specific load telemetered using tieline telemetry to both the original Load Host and Supply Host. The telemetry is incorporated into the ACE equation of both Control Areas as a new point of interconnection. The [remote control-area load] is effectively transferred completely from the original Load Host to the Supply Host and the Supply Host becomes the Load Host for control purposes."

A specific example will help to explain the mechanics of DS. Consider the dynamic scheduling of $\mathrm{L} 1$ from control area (CA) A to CA C (Fig. 1). Although L1 is time-varying, we consider a single period as a snapshot. We first consider the situation without DS of Ll (top half of Table 2) and then with DS (bottom half of Table 2). To simplify the example, we ignore the frequency-bias term because it does not change with DS.

At this instant, CA A is generating $8572 \mathrm{MW}$, its total load (including L1) is $8812 \mathrm{MW}$, and therefore its actual interchange is $-240 \mathrm{MW}$ (= generation - load). (Positive flows are from inside to outside the control area.) Its scheduled interchange is $-150 \mathrm{MW}$. Together, these figures yield an instantaneous ACE of $-90 \mathrm{MW}[-240-(-150)=-90]$, which means that CA $A$ is slightly undergenerating at this instant. At this same time, $C A C$ is generating $5781 \mathrm{MW}$, its load is $5902 \mathrm{MW}$, and therefore its actual interchange is $-121 \mathrm{MW}$. Its scheduled interchange is $-100 \mathrm{MW}$, yielding an instantaneous ACE of $-21 \mathrm{MW}$. Thus, CA C is also slightly undergenerating.

With DS, the $700 \mathrm{MW}$ of $\mathrm{Ll}$ is subtracted from the scheduled interchange for CA A. Thus, it appears in CA A's ACE equation as a negative number in the scheduled interchange; a load flowing out of the control area is equivalent to generation flowing into the control area. This change in schedule would, absent any additional action from CA A, increase its ACE from -90 to $+610 \mathrm{MW}$. In response to signals from its AGC system to meet the $\mathrm{A} 1$ and $\mathrm{A} 2$ criteria, assumed in this case to restore ACE to its original value, CA A must decrease its actual interchange by the same $700 \mathrm{MW}$, which its AGC system does by decreasing its generation by $700 \mathrm{MW}$. With DS, L1 is added to the scheduled interchange and, therefore, appears in CA C's $\mathrm{ACE}$ equation as a positive number in the scheduled interchange. This change in the $\mathrm{ACE}$ equation decreases CA C's ACE by $700 \mathrm{MW}$, which is then offset by an increase in generation within $\mathrm{CAC}$ of $700 \mathrm{MW}$.

In the second approach described above (remote control-area load), the transfer of Ll is treated as a new point of interconnection between the two control areas (pseudo-tieline). In this case, the actual interchange terms in the ACE equations, rather than the scheduled interchange terms, are adjusted. Table 3 shows the mechanics of transferring load for the same 
situation as that discussed above and shown in Table 2. Although the values of $\mathrm{I}_{\mathrm{A}}$ and $\mathrm{I}_{\mathrm{S}}$ are different in this case from the one with DS, the end results are identical: CA C increases and $\mathrm{CA}$ A decreases generation by $700 \mathrm{MW}$ to restore $\mathrm{ACE}$ to the original values.

The example discussed above assumed that there are no incremental losses associated with the electronic transfer of $\mathrm{Ll}$ from $\mathrm{A}$ to $\mathrm{C}$. In practice, losses are likely to increase because

Table 2. Numerical example showing adjustments to the ACE equation with dynamic scheduling of $700 \mathrm{MW}$ of load from Control Area A to Control Area C

\begin{tabular}{|c|c|c|c|}
\hline Case & $\begin{array}{l}+\mathrm{I}_{\mathrm{A}} \text { (actual } \\
\text { interchange) }\end{array}$ & $\begin{array}{l}\text { - IS (scheduled } \\
\text { interchange) }\end{array}$ & $\begin{array}{c}=\mathrm{ACE} \\
\text { (area-control error) }\end{array}$ \\
\hline \multicolumn{4}{|c|}{ Without dynamic scheduling } \\
\hline CA A & -240 & +150 & -90 \\
\hline CA C & -121 & +100 & -21 \\
\hline \multicolumn{4}{|c|}{ With dynamic scheduling of $700 \mathrm{MW}$ of load from $\mathrm{A}$ to $\mathrm{C}$} \\
\hline CA A & -240 & $-(-150-700)$ & +610 \\
\hline CA $A$ adjusted ${ }^{a}$ & $-240-700$ & $-(-150-700)$ & -90 \\
\hline $\mathrm{CAC}$ & -121 & $-(-100+700)$ & -721 \\
\hline CA C adjusted ${ }^{\mathrm{a}}$ & $-121+700$ & $-(-100+700)$ & -21 \\
\hline
\end{tabular}

Table 3. Numerical example showing adjustments to the ACE equation with pseudotieline transfer of $700 \mathrm{MW}$ of load from Control Area A to Control Area C

\begin{tabular}{lccc}
\hline Case & $\begin{array}{c}\mathrm{I}_{\mathrm{A}} \text { (actual } \\
\text { interchange) }\end{array}$ & $\begin{array}{c}-\mathrm{I}_{\mathrm{S}} \text { (scheduled } \\
\text { interchange) }\end{array}$ & $\begin{array}{c}=\mathrm{ACE} \\
\text { (area-control error) }\end{array}$ \\
\hline
\end{tabular}

Without pseudo-tieline
CA A
$-240$
$+150$
$-90$
$\mathrm{CAC}$
$-121$
$+100$
$-21$

With pseudo-tieline transfer of $700 \mathrm{MW}$ of load from $\mathrm{A}$ to $\mathrm{C}$

\begin{tabular}{|c|c|c|c|}
\hline $\mathrm{CAA}$ & $-240-700$ & +150 & -790 \\
\hline CA A adjusted ${ }^{a}$ & $-240-700+700$ & +150 & -90 \\
\hline $\mathrm{CAC}$ & $-121+700$ & +100 & \\
\hline CA C adjusted $^{a}$ & $-121+700-700$ & +100 & \\
\hline
\end{tabular}

${ }^{\mathrm{a}}$ The adjustments are made to generation to restore ACE to its original (without DS) values. 
the generation being "dispatched" to meet $\mathrm{Ll}$ is likely to be electrically more distant from $\mathrm{Ll}$ than was true in the no-DS case. Assume, for purposes of this example, that the electronic transfer of $\mathrm{L} 1$ increases losses by $10 \mathrm{MW}$, with $4 \mathrm{MW}$ occurring within CA A and $6 \mathrm{MW}$ within CA C. (We ignore any change in losses within CA B.)

The actual interchange out of CA A will be $4 \mathrm{MW}$ less than in the case without losses $\left[\mathrm{I}_{\mathrm{A}}=-240-(700+4)\right]$ because the load in $\mathrm{A}$ is increased by these losses. To maintain the same ACE, CA A now needs to increase generation by $4 \mathrm{MW}$ [i.e., to decrease generation by $696 \mathrm{MW}(700-4)]$. Similarly, the actual interchange out of CA C will be $6 \mathrm{MW}$ less than in the case without losses $\left[I_{A}=-121+(700-6)\right]$. So CA $C$ needs to increase generation by 706 MW $(700+6)$ to maintain its $\mathrm{ACE}$ at the same value. These changes will occur automatically as each control area's AGC system adjusts its generation to maintain ACE.

*Alternatively, the two control areas could agree that $\mathrm{CA} C$ is to cover all $10 \mathrm{MW}$ of incremental losses. In that case, the scheduled interchange between $A$ and $C$ would be increased by $4 \mathrm{MW}$ so that $\mathrm{CA} A$ does not provide any generation for these incremental losses. 


\section{REASONS TO USE DYNAMIC SCHEDULING}

Perhaps the most powerful reason to offer dynamic scheduling is that it promotes competition and increases choice; it allows electricity consumers to purchase certain services from entities outside their physical-host control area and allows generators to sell certain services to entities other than their physical host. Increasing the number of possible suppliers and consumers increases competition, which should encourage innovation and reduce costs and prices. If such choices become widely available and used throughout the country, FERC may decide to relax the requirements it now imposes on transmission providers to offer six ancillary services to transmission customers at regulated prices. Instead, some of these services could be provided voluntarily at market-determined prices.

Various factors might motivate the use of DS; several examples are presented in Chapter 4. The most frequent example of DS is for jointly owned generating units. Dynamic scheduling of a load (e.g., a municipality) from one control area to another is also common.

An entity that manages loads in more than one control area (e.g., a manufacturer with facilities in several control areas) might want to aggregate its load and purchase all its electrical needs from one provider. Such aggregation can reduce costs for some services, especially regulation (Hirst and Kirby 1996). Table 4 shows hourly statistics based on 10-second data for three separately metered components of the load at an aluminum plant in the Pacific Northwest as well as the plant's total load. Clearly, aggregation reduces the volatility of the load that generators must serve. For example, the sum of the ranges of the three components is $23 \mathrm{MW}$, but the range for the total load is less than $14 \mathrm{MW}$, a $40 \%$ reduction. (The range is the difference between the highest and lowest 10-second reading during the hour.)

Similarly, the manager of several generating units located in several control areas might want to aggregate their outputs and sell all the basic energy and capacity, as well as ancillary services, to a single customer or another control area. In addition, cost reductions might motivate DS. For example, if control area $\mathrm{C}$ pays higher prices for generation-related ancillary services (such as regulation, spinning reserve, and supplemental reserve) than does control area $A$, a generator located in control area A might want to dynamically schedule its output to $C$. 
Table 4. The effects of aggregation on regulating requirements for an industrial customer

\begin{tabular}{lccccc}
\hline & $\begin{array}{c}\text { Load } \\
\# 1\end{array}$ & $\begin{array}{c}\text { Load } \\
\# 2\end{array}$ & $\begin{array}{c}\text { Load } \\
\# 3\end{array}$ & $\begin{array}{c}\text { Sum of } \\
\text { loads }\end{array}$ & Metered total \\
\hline Mean (MW) & 84 & 98 & 88 & 270 & 270 \\
Standard deviation (MW) & 2.4 & 1.1 & 0.9 & 4.4 & 2.4 \\
Range (MW) & 12.7 & 5.5 & 4.8 & 23.0 & 13.6 \\
\hline
\end{tabular}

Many smaller utilities, especially public power entities, provide services to customers that are widely scattered across several control areas. For example, American Municipal PowerOhio (AMP-Ohio 1996) petitioned FERC to make DS a required service, one that transmission providers must make available to transmission customers:

Dynamic scheduling is necessary for entities such as AMP-Ohio, which has 77 members as well as generation located throughout Ohio in 7 control areas, to permit integration across separate control areas and otherwise make provisions for entities that are connected to more than one control area to take full advantage of network service. Indeed, utilities such as AMP-Ohio must have the ability to obtain network [transmission] service that permits them to serve member systems in more than one control area. Many transmission providers operate their system in this fashion, as jointly owned generation units in one joint owner's control area are dynamically dispatched to serve load in another joint owner's control area.

Although intended to increase choices and lower costs, DS does not necessarily lead to a reduction in costs. To explore the possible effects of dynamically scheduling a load from one control area to another, we created a pair of control areas. Starting with two hours of 10-second data on actual and scheduled interchange, frequency, frequency bias, ACE, generation, and load from a large utility, we created 1 hour of simulated 30 -second data for two control areas. We then simulated the transfer of a particular load ( $\mathrm{Ll}$ ) from control area $\mathrm{A}$ to control area B, using different assumptions about the time-varying nature of L1. Specifically, we defined Ll, measured in $\mathrm{MW}$, as:

$$
\mathrm{Ll}=\mathrm{a}+(\mathrm{b} \times \mathfrak{t})+(\mathrm{c} \times \text { random })+(\mathrm{d} \times \text { GenA fluctuation })+(\mathrm{e} \times \text { GenB fluctuation }),
$$

where $a, b, c, d$, and e are constants input by the user to simulate different conditions; $t$ is time measured in 30-second increments, random is a random number with a mean of 0 , GenA fluctuation is the instantaneous difference between the actual value of generation and the generation trend during this hour for CA A. Thus, $\mathrm{Ll}$ can include (1) a component that varies linearly with time to simulate the need for interhour load following, (2) a random component 
to simulate the need for regulation (intrahour load following), and (3) components correlated with the time-varying generation in either or both control areas. Not surprisingly, as we varied the five coefficients, the effects on the two control areas also varied.

Table 5 shows that the effects of electronically transferring a load depend on the nature of the load as well as on the characteristics of the generation in both control areas. In this example, the transferred load increases linearly by $60 \mathrm{MW}$ during this hour, imposing a loadfollowing burden of $60 \mathrm{MW} /$ hour on its host control area. Because the generation in both control areas follows a quadratic curve during this hour (first decreasing slightly and then increasing in $\mathrm{A}$; increasing and then decreasing in B), the effects of transferring the load are nonlinear. Specifically, the load-following need in A declines by only $42 \mathrm{MW}$, and that in B increases by only $33 \mathrm{MW}$, even though the transferred load has a trend of $60 \mathrm{MW} / \mathrm{hour}$. Thus, the overall effect of DS on load following is a $15 \%$ reduction [(42-33)/60], with the benefits shared unequally.

The changes in regulating requirement [measured here as the average of the absolute values of the 30-second load fluctuations and the average of the absolute values of the ramp rate (MW/minute)] depend on the amount of random fluctuation in Ll and its correlations, if any, with generation movements in $\mathrm{A}$ and $\mathrm{B}$. If $\mathrm{Ll}$ is uncorrelated with the generation fluctuations in both control areas, its transfer from $A$ to $B$ has little effect on the amount of regulation required and increases slightly the ramp rate for regulation in both control areas.

If the Ll fluctuations are correlated with the generation fluctuations in A, the load's transfer from $\mathrm{A}$ to $\mathrm{B}$ reduces the regulation requirement (both $\mathrm{MW}$ and $\mathrm{MW} /$ minute) in $\mathrm{A}$ and increases it, although by a smaller amount, in $\mathrm{B}$. If the $\mathrm{L} l$ fluctuations are negatively correlated with the generation fluctuations in B, the load's transfer from A to B reduces the regulation requirement (both $\mathrm{MW}$ and $\mathrm{MW} /$ minute) in $\mathrm{B}$ and increases it, although by a smaller amount, in $\mathrm{A}$.

In summary, these examples suggest that DS often reduces the total load-following and regulating burdens. However, the extent and allocation of these benefits depend on the correlations between the dynamically scheduled load and the generation and remaining load in both control areas. (In general, there should be little intrahour correlation between any single load and the total system load.) 
Table 5. The effects on the load-following and regulating requirements of control areas $A$ and $B$ associated with the electronic transfer of Load 1 from $A$ to $B$

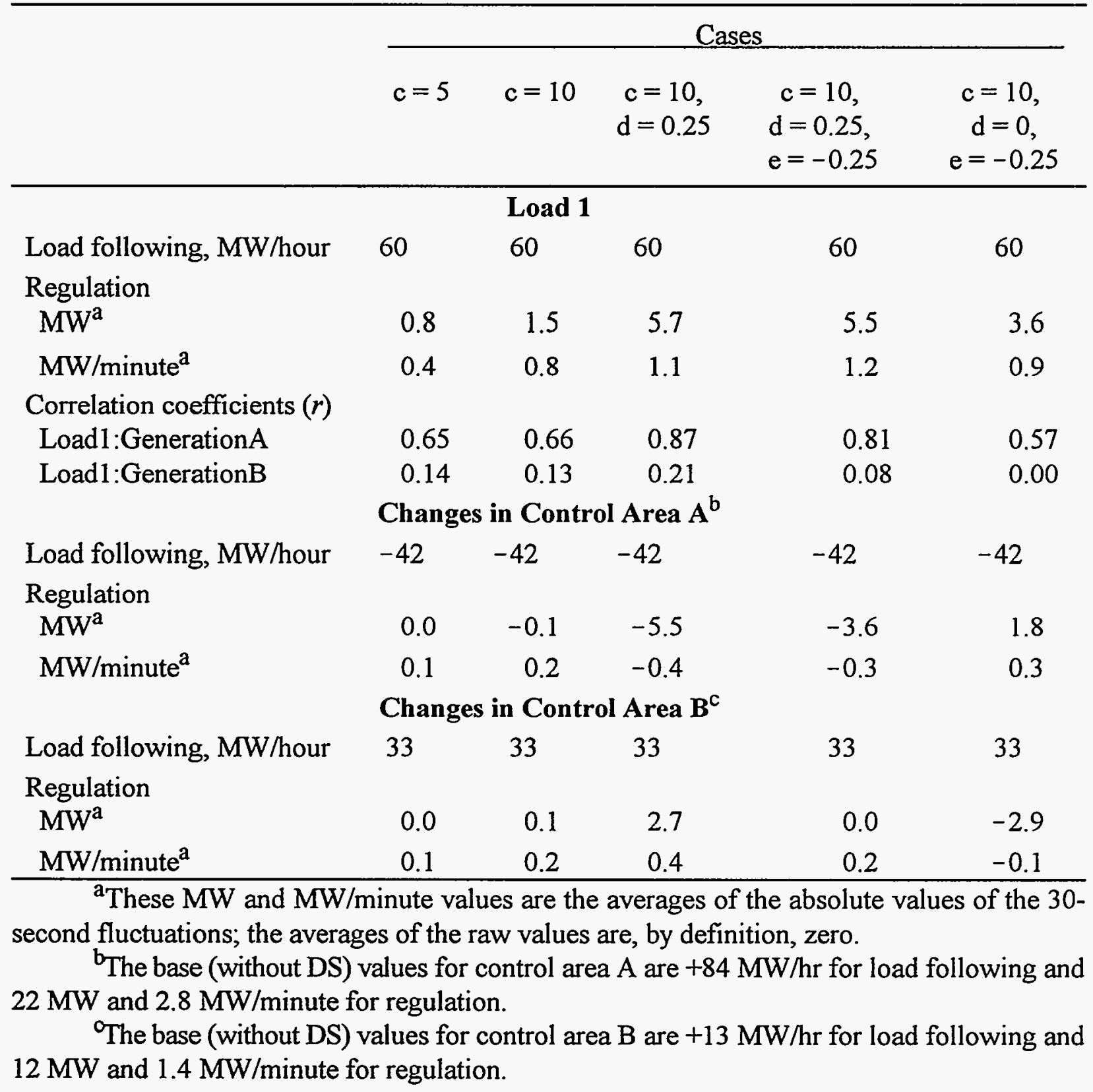




\section{EXAMPLES OF DYNAMIC SCHEDULING}

Our telephone interviews with utility staff throughout the country uncovered many examples of dynamically scheduled generation and loads. Some of these are summarized in Tables 6 and 7.

\section{GENERATION}

In some of the generation examples, the units are used for regulation, and in other cases they are not. The 17 hydroelectric units at Hoover Dam are operated by the Western Area Power Administration (WAPA). Four other control areas in the Southwest send signals to WAPA every four seconds, requesting time-varying amounts of generation (up to their contractual allocations); because hydro units respond very quickly compared with fossil units, the four control areas use their Hoover rights for regulation. ${ }^{*}$ WAPA aggregates the four requests and sends the total to the control system and Hoover Dam. In addition, WAPA automatically sends an echo signal back to each control area to confirm receipt of, and response to, its generation request.

Similarly, Otter Tail Power (OTP) purchases supplemental regulation and load following from Manitoba Hydro because Manitoba Hydro's hydroelectric units can provide faster regulation service at lower cost than can OTP. Manitoba Hydro and OTP, as well as other Minnesota utilities, conducted tests in which AGC control was shared between the requesting and controlling control areas (Prowse at al. 1994). These tests showed little benefit because units under AGC in both utilities were moving all the time. The Manitoba hydro units on regulation responded much more rapidly to AGC requests than did the Minnesota thermal units; the Minnesota utilities did not experience a reduction in their regulation burden primarily because of this disparity in response rate (MW/minute). This lack of performance improvement was a consequence of inappropriate control logic, not of DS per se.

A second test, in which control was fully transferred from the Minnesota utilities to Manitoba Hydro, worked much better. The idea in this second test was to reduce the reversals in direction (i.e., sign changes) of the units on control. The requesting control area still provided interhour load following, but Manitoba Hydro followed the short-term random fluctuations (regulation). The purpose was to "transfer AGC regulation and not energy." On the basis of

*Each turbine-generator can ramp at up to $20 \mathrm{MW} /$ minute; thus, the plant can go from zero to full output within 7 minutes. Fossil units might require an hour or more to ramp from minimum to full output. 
Table 6. Examples of dynamic scheduling of generation among U.S. electric utilities

\begin{tabular}{|c|c|c|c|}
\hline Physical host & Electronic host & Size $(\mathrm{MW})$ & Comments \\
\hline $\begin{array}{l}\text { Westem Area } \\
\text { Power } \\
\text { Administration } \\
\text { (WAPA) }\end{array}$ & $\begin{array}{l}\text { Southern California } \\
\text { Edison, Los Angeles, } \\
\text { Nevada Power, Salt River } \\
\text { Project (SRP) }\end{array}$ & $\begin{array}{l}1951 \mathrm{MW}, 17 \text { units } \\
\text { at Hoover Dam }\end{array}$ & $\begin{array}{l}\text { Each of the four control areas sends AGC } \\
\text { signals to WAPA, which aggregates them } \\
\text { and sends total to Hoover computer; units } \\
\text { used extensively for regulation }\end{array}$ \\
\hline Manitoba Hydro & Otter Tail Power (OTP) & Several hydro units & $\begin{array}{l}\text { Manitoba Hydro provides } \pm 25 \mathrm{MW} \text { of } \\
\text { regulation for OTP; OTP provides } \\
\text { supplemental regulation outside this } \\
\text { bandwidth }\end{array}$ \\
\hline Montana Power & $\begin{array}{l}\text { Puget Power, PacifiCorp, } \\
\text { Washington Water Power, } \\
\text { Portland General Electric }\end{array}$ & $\begin{array}{l}\text { Two } 330-\mathrm{MW} \text { plus } \\
\text { two } 700-\mathrm{MW} \text { coal } \\
\text { units at Colstrip }\end{array}$ & Units used for baseload, not for regulation \\
\hline PacifiCorp-east & PacifiCorp-west & $\begin{array}{l}1500 \mathrm{MW} \text { from } \\
\text { Wyoming and Utah } \\
\text { coal plants }\end{array}$ & $\begin{array}{l}\text { East-to-west flow passes through Idaho } \\
\text { Power; PacifiCorp pays for } 1600 \mathrm{MW} \text { of } \\
\text { transmission capacity (including } 100 \mathrm{MW} \\
\text { for regulation) }\end{array}$ \\
\hline $\begin{array}{l}\text { Arizona Public } \\
\text { Service (APS) }\end{array}$ & Six utilities in Southwest & $\begin{array}{l}2250 \mathrm{MW} \text { in three } \\
\text { Navajo units }\end{array}$ & $\begin{array}{l}\text { Baseload units, not used for regulation; } \\
\text { SRP operates plant, located in APS control } \\
\text { area, output shared among six utilities }\end{array}$ \\
\hline $\begin{array}{l}\text { Salt River Project } \\
\text { (SRP) }\end{array}$ & $\begin{array}{l}\text { Seven utilities in } \\
\text { Southwest }\end{array}$ & $\begin{array}{l}3663 \mathrm{MW} \text { in three } \\
\text { Palo Verde units }\end{array}$ & $\begin{array}{l}\text { Baseload units, not used for regulation; } \\
\text { APS operates plant, located in SRP control } \\
\text { area, output shared among seven utilities }\end{array}$ \\
\hline Ohio Edison (OE) & $\begin{array}{l}\text { Cleveland Electric } \\
\text { Illuminating, Duquesne } \\
\text { Light, Toledo Edison }\end{array}$ & $\begin{array}{l}2960 \mathrm{MW} \text { in four } \\
\text { coal units }\end{array}$ & $\begin{array}{l}\text { Units used for regulation, with ramp rate } \\
\text { shared among owners proportional to } \\
\text { ownership shares. OE aggregates dynamic } \\
\text { requests from four owners }\end{array}$ \\
\hline APS & Six utilities in Southwest & $\begin{array}{l}1568 \mathrm{MW} \text { in two } \\
\text { Four Comers units }\end{array}$ & Baseload units, not used for regulation \\
\hline APS & San Diego Gas \& Electric & $\begin{array}{l}55 \mathrm{MW} \text { at } \\
\text { independent power } \\
\text { producer (IPP) }\end{array}$ & $\begin{array}{l}\text { Output from IPP in APS service area } \\
\text { telemetered to San Diego, not used for } \\
\text { regulation }\end{array}$ \\
\hline APS & PacifiCorp & $\begin{array}{l}\text { 370-MW Cholla } \\
\text { No. } 4\end{array}$ & $\begin{array}{l}\text { Output transferred from APS to Paciticiorp } \\
\text { at Four Comers }\end{array}$ \\
\hline $\begin{array}{l}\text { PJM } \\
\text { Interconnection }\end{array}$ & $\begin{array}{l}\text { New York State Electric \& } \\
\text { Gas (NYSEG) }\end{array}$ & $\begin{array}{l}1884 \mathrm{MW}, \text { Homer } \\
\text { City plant with three } \\
\text { units }\end{array}$ & $\begin{array}{l}\text { Plant is owned } 50: 50 \text { by NYSEG and } \\
\text { General Public Utilities (part of PJM), } \\
\text { baseload operation, not used for regulation }\end{array}$ \\
\hline Entergy & $\begin{array}{l}\text { South Mississippi Electric } \\
\text { Power Association }\end{array}$ & $\begin{array}{l}1100-\mathrm{MW} \text { Grand } \\
\text { Gulf nuclear unit }\end{array}$ & $\begin{array}{l}\text { Association receives } 10 \% \text { of (irand (iulf } \\
\text { output at all times, unit not used for } \\
\text { regulation }\end{array}$ \\
\hline $\begin{array}{l}\text { Lower Colorado } \\
\text { River Authority } \\
\text { (LCRA) }\end{array}$ & City of Austin & $\begin{array}{l}\text { Two } 600-\mathrm{MW} \text { coal } \\
\text { units }\end{array}$ & $\begin{array}{l}\text { LCRA dispatches units based on requests } \\
\text { from both utilities, generally used for } \\
\text { baseload }\end{array}$ \\
\hline PacifiCorp & $\begin{array}{l}\text { Puget Power, Washington } \\
\text { Water Power, Portland } \\
\text { General Electric, Seattle, } \\
\text { Tacoma, Snohomish, } \\
\text { Grays Harbor }\end{array}$ & $\begin{array}{l}\text { Two } 700-\mathrm{MW} \text { coal } \\
\text { units at Centralia }\end{array}$ & Units used for baseload, not for regulation \\
\hline Southern Company & $\begin{array}{l}\text { Jacksonville Electric } \\
\text { Authority }\end{array}$ & $\begin{array}{l}\text { 820-MW Scherer } \\
\text { No. } 4\end{array}$ & $\begin{array}{l}\text { Southern AGC treats unit output as a } \\
\text { tieline; adjusted for assumed 3\% loss }\end{array}$ \\
\hline
\end{tabular}


these tests, OTP began receiving up to $50 \mathrm{MW}$ of regulation service from Manitoba Hydro in October 1990. OTP's compliance with the A1 and A2 criteria has improved substantially, from below $80 \%$ before obtaining regulation service from Manitoba to above $98 \%$ since then.

The four Colstrip units in Montana are operated by Montana Power, on behalf of several owners. Although these units are operated in baseload mode, rather than as regulating units, DS still made sense. Absent DS, all the errors in plant output (i.e., differences between actual and scheduled output) would contribute to Montana Power's inadvertent interchange but not to that of the other owners. Dynamically scheduling the units equitably shares any errors in plant output and also reduces the need for control-area and plant operators to manually change schedules.

PacifiCorp operates generating stations and serves loads in seven northwestern states (Washington, Oregon, California, Montana, Idaho, Utah, and Wyoming). Most of its generation is in its eastern division (Utah and Wyoming), while most of its load is in its western division. The generators in the east are primarily large coal units. The generators in the west are primarily hydro units. Prior to the merger that created PacifiCorp, the two original utilities operated separate control centers in Salt Lake City, Utah, and Portland, Oregon. Now, PacifiCorp operates its entire system from its Portland facility. This consolidation allows PacifiCorp to use the eastern units for baseload capacity in the west and to use the western hydro units for regulation in the east. The Idaho Power system lies between the two PacifiCorp divisions. PacifiCorp purchased firm transmission rights for $1600 \mathrm{MW}$ of capacity flowing from east to west across the Idaho Power system. Of this total, $1500 \mathrm{MW}$ is used for base capacity, and the additional $100 \mathrm{MW}$ is assigned to regulation. PacifiCorp also compensates Idaho Power for losses on the Idaho transmission system on the basis of contractually agreed upon assumptions, not on the basis of metered flow or detailed calculations.

Several utilities in the southwest co-own several generating units (Fig. 2). The outputs from these units are dynamically scheduled from the plant's operator to the other owners. The coal-fired Navajo station is operated by the Salt River Project (SRP) but is physically located within the control area of Arizona Public Service (APS). The reverse is true for the Palo Verde nuclear plant, which is operated by APS and located within the SRP control area.

Ohio Edison operates four coal units that it co-owns with three other Ohio utilities. The four utilities have agreed on loss factors. These loss factors vary with season and for on- and off-peak hours for each of the four utilities. The loss allocation is done on a minute-to-minute basis with these loss factors. Ohio Edison then schedules generation output as the sum of the owners' requests plus the calculated loss adjustments. The four utilities developed a system that allows each utility to independently baseload, ramp, or regulate with its share of the jointly owned units (Might et al. 1978). 


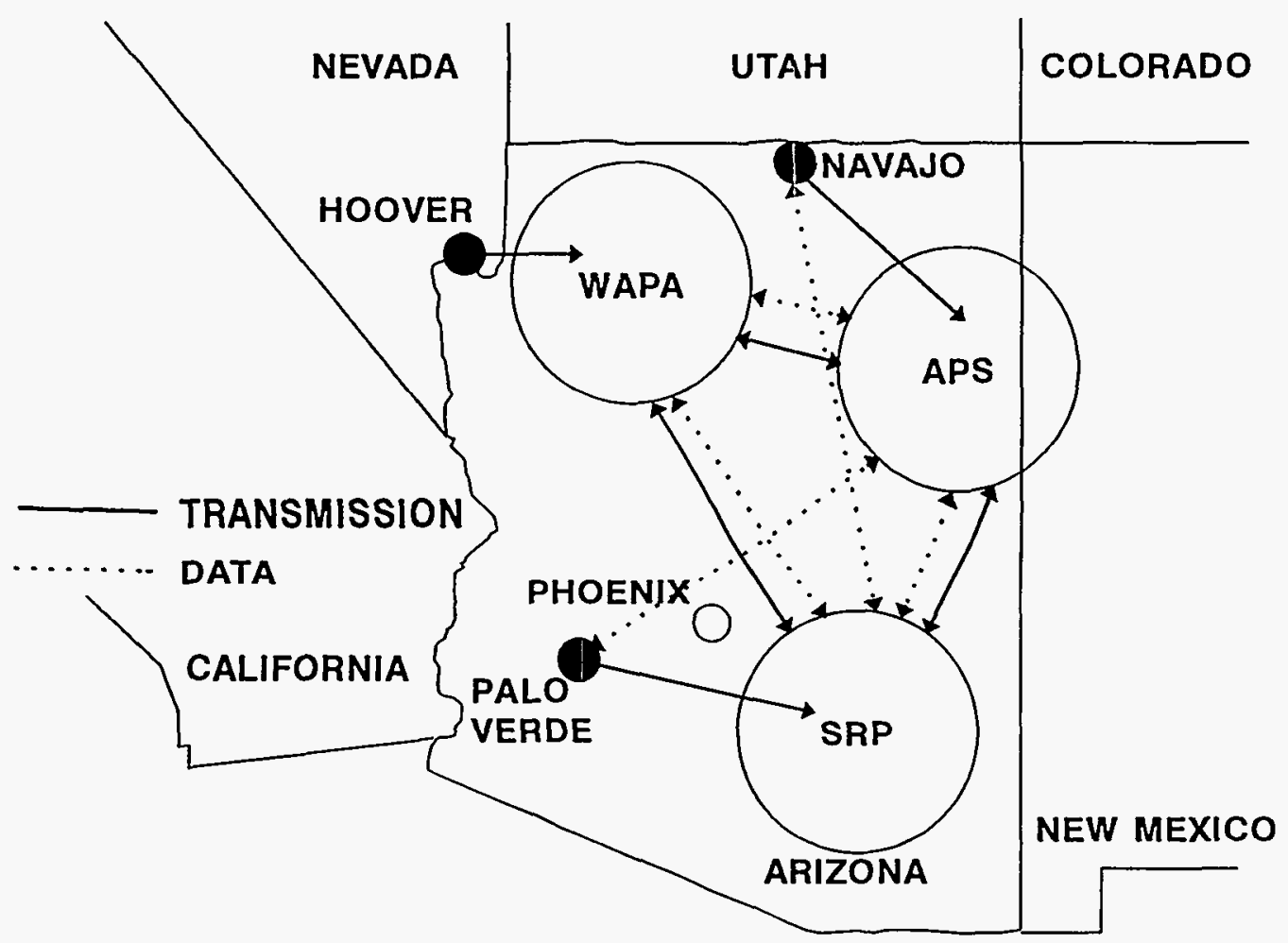

Fig. 2. Schematic representation of the APS, SRP, and WAPA control areas in Arizona. The control areas overlap each other, and all three control centers are located in Phoenix.

These examples of dynamically scheduled generation show that there are two options, one-way and two-way scheduling. In one-way scheduling, telemetered signals are sent from the generator to the various control centers. In two-way scheduling, the various control centers telemeter time-varying output requests to the generator, which then telemeters its output back to the control centers.

\section{LOADS}

The examples of dynamically scheduled load show that the amounts of power transferred are generally much smaller per delivery point than for generation (Table 7). For example, the Geneva, Illinois load of about $45 \mathrm{MW}$ is the aggregate of loads collected at eight points on the Commonwealth Edison transmission system. In this case, the city of Geneva aggregates the load and then sends the aggregate signal to both Commonwealth Edison (the physical host) and Wisconsin Electric (the electronic host).

The Cajun Electric Power Cooperative load, which is scattered throughout the service territories of four investor-owned utilities, involves the separate metering and telemetering of loads from about 125 points to the Cajun control center as well as to the physical-host control centers. On average, each load point is about $10 \mathrm{MW}$. (Although not shown in Tables 6 and 7, Cajun also uses DS for five generating units that it operates and that are located outside its 
control area.) Cajun has many transmission contracts with the surrounding utilities to cover these transactions. Losses are handled on a contractual basis, depending on the utility and the voltage levels at which loads are measured. For example, Cajun has a load of $400 \mathrm{MW}$ on the Louisiana Power \& Light system, of which $75 \%$ is served at the transmission level with an assumed loss of $2 \%$ and the remainder at the distribution level with an assumed loss of $5 \%$ (Elmer 1996). Cajun transmits its generation to serve these loads across the Gulf States Utilities system, with losses set at $1.1 \%$. Thus, to serve the $400 \mathrm{MW}$ of load, Cajun must generate 415.5 $\mathrm{MW}\{=[1.011 \times(300 \times 1.02+100 \times 1.05)]\}$.

The Central Arizona Project is perhaps the most interesting example uncovered in this study because it involves the simultaneous scheduling of loads and generation (Fig. 2) and, therefore, appears in both Tables 6 and 7. The Project brings Colorado River water to the areas around Phoenix and Tucson in Arizona; it is the largest irrigation project in the world. The Project includes 15 major pumping stations with a load of about $550 \mathrm{MW}$, all in WAPA's control area. WAPA dynamically aggregates these loads and sends the aggregate signal to the Salt River Project control center (in Phoenix). SRP meets the Project's load with output from the coal-fired Navajo plant (in Page, Arizona). SRP meets any regulation requirements for the Project from its overall resource pool. The Navajo plant is located in the Arizona Public Service control area, so APS schedules the plant's output across its transmission system. The three Navajo units (741 MW each) total $2223 \mathrm{MW}$ and are co-owned by six utilities: Los Angeles Department of Water and Power, Nevada Power, Tucson Electric, SRP, WAPA, and APS. APS is the physical host for the power plant, and SRP is the electronic host (Table 6). WAPA is the physical host for the Project load, and SRP is the electronic host (Table 7).

The Lower Colorado River Authority (LCRA) traditionally had difficulty meeting its performance criteria, primarily because of a volatile steel-mill load in its service area with a load that can change rapidly by as much as $100 \mathrm{MW}$. Beginning in January 1995, LCRA purchased supplemental regulation service from Houston Lighting \& Power (HL\&P), Since then, LCRA's compliance with the NERC A2 criterion has improved from $74 \%$ to over $92 \%$ (Trefny et al. 1996). LCRA uses its own generating units to provide regulation service within a \pm 12 - or $\pm 25-\mathrm{MW}$ bandwith. When the LCRA ACE moves outside this bandwith, usually because of steel-mill operations, HL\&P provides supplemental regulation to move the ACE back within the bandwith (Fig. 3). This transfer is profitable for both utilities, in part because HL\&P's generating capacity is about six times as much as LCRA's. Figure 4 shows the data flows between the two control centers associated with this dynamically scheduled supplemental-regulation service. This supplemental regulation can be considered either DS of load or of generation. In one sense, this example is the inverse of what Manitoba Hydro provides to OTP. In another sense, LCRA is dynamically scheduling the volatility associated with its steel-mill load to HL\&P. Because the two control areas are generally not contiguous, LCRA pays wheeling charges plus loss charges to the intervening utilities. 
Table 7. Examples of dynamic scheduling of load among U.S. electric utilities

\begin{tabular}{|c|c|c|c|}
\hline Physical host & Electronic host & Size (MW) & Comments \\
\hline $\begin{array}{l}\text { Commonwealth } \\
\text { Edison }\end{array}$ & $\begin{array}{l}\text { Wisconsin } \\
\text { Electric }\end{array}$ & $\begin{array}{l}-45 \mathrm{MW} \text { in } \\
\text { Geneva, } \\
\text { Illinois }\end{array}$ & $\begin{array}{l}\text { Eight } 34.5-\mathrm{kV} \text { delivery points; data } \\
\text { aggregated in Geneva and sent to both } \\
\text { control centers; two utilities are adjacent, } \\
\text { which simplifies transmission and loss } \\
\text { considerations }\end{array}$ \\
\hline $\begin{array}{l}\text { Entergy, Central } \\
\text { Louisiana Electric, } \\
\text { Southwestern } \\
\text { Electric Power }\end{array}$ & $\begin{array}{l}\text { Cajun Electric } \\
\text { Power } \\
\text { Cooperative }\end{array}$ & $\begin{array}{l}\sim 1200 \mathrm{MW} \text { of } \\
\text { distribution- } \\
\text { coop load }\end{array}$ & $\begin{array}{l}\text { About } 125 \text { metering points at voltage levels } \\
\text { ranging from } 13.2 \text { to } 230 \mathrm{kV} \text { within control } \\
\text { areas of these four utilities, signals } \\
\text { telemetered to Cajun control center }\end{array}$ \\
\hline WAPA & SRP & $\begin{array}{l}550 \mathrm{MW} \text { of } \\
\text { irrigation } \\
\text { pumping }\end{array}$ & $\begin{array}{l}\text { Central Arizona Project has } 15 \text { major } \\
\text { pumping stations, all within the WAPA } \\
\text { control area; loads telemetered to SRP, } \\
\text { which meets load with Navajo station, } \\
\text { located in the APS control area }\end{array}$ \\
\hline LCRA & $\begin{array}{l}\text { Houston Lighting } \\
\text { \& Power (HL\&P) }\end{array}$ & $\begin{array}{l}75 \mathrm{MW} \text { of } \\
\text { regulation }\end{array}$ & $\begin{array}{l}\text { HL\&P provides regulation when LCRA's } \\
\text { ACE exceeds about } \pm 12 \mathrm{MW}\end{array}$ \\
\hline Southern Company & $\begin{array}{l}\text { Tennessee Valley } \\
\text { Authority (TVA) }\end{array}$ & $\begin{array}{l}50 \mathrm{MW} \text { in } \\
\text { northern } \\
\text { Georgia }\end{array}$ & $\begin{array}{l}\text { Analog signal represents sum of } 20 \text { delivery } \\
\text { points, scheduled from Southern to TVA. } \\
\text { with monthly trueups }\end{array}$ \\
\hline Southern Company & $\begin{array}{l}\text { Alabama Electric } \\
\text { Cooperative } \\
\text { (AEC) }\end{array}$ & $\begin{array}{l}\text { 100 MW in } \\
\text { Alabama }\end{array}$ & $\begin{array}{l}\text { AEC meters only a sample of the loads, } \\
\text { scales them up to approximate total load, and } \\
\text { sends signal to Southern as a pseudo-tieline: } \\
\text { actual usage is trued up monthly. }\end{array}$ \\
\hline $\begin{array}{l}\text { Six Florida } \\
\text { municipal utilities }\end{array}$ & $\begin{array}{l}\text { Orlando Utilities } \\
\text { Commission }\end{array}$ & $500 \mathrm{MW}$ & $\begin{array}{l}\text { These loads, collected at } 14 \text { points at several } \\
\text { voltage levels, are not contiguous to each } \\
\text { other; losses are handled through contracts } \\
\text { with Florida Power \& Light and Florida } \\
\text { Power Corp. }\end{array}$ \\
\hline $\begin{array}{l}\text { Texas-New Mexico } \\
\text { Power (TNP) }\end{array}$ & HL\&P & $\begin{array}{l}430 \mathrm{MW} \text { from } \\
\text { three sources }\end{array}$ & $\begin{array}{l}\text { HL\&P provides generation (including } \\
\text { regulation) to meet the difference between } \\
\text { the TNP load and the output of two } \\
\text { cogenerators (both located in HL\&P area) } \\
\text { used to supply that load }\end{array}$ \\
\hline WAPA & APS & $\begin{array}{l}270 \mathrm{MW} \text { of } \\
\text { load in various } \\
\text { locations }\end{array}$ & $\begin{array}{l}15 \text { load-metering points, the WAPA and } \\
\text { APS control areas are adjacent to each other }\end{array}$ \\
\hline ОТР & $\begin{array}{l}\text { Northern States } \\
\text { Power (NSP) }\end{array}$ & $\begin{array}{l}-410 \mathrm{MW} \text { of } \\
\text { load }\end{array}$ & $\begin{array}{l}\text { NSP loads are located in or near two cities in } \\
\text { the OTP control area; NSP collects load data } \\
\text { and aggregates the signal before sending to } \\
\text { OTP }\end{array}$ \\
\hline
\end{tabular}




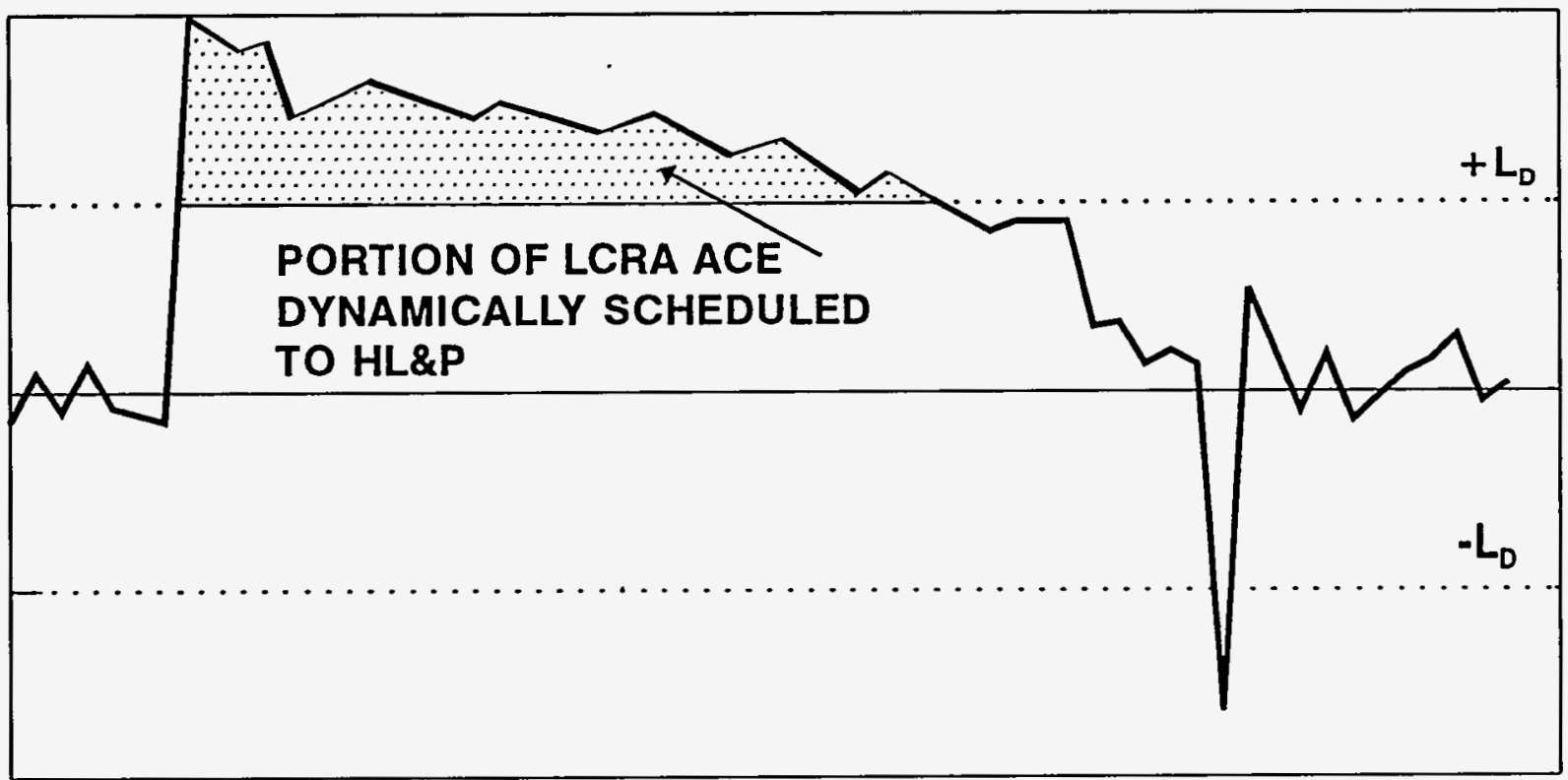

TIME

Fig. 3. Area-control error for LCRA showing the portion of ACE that is dynamically scheduled to HL\&P.

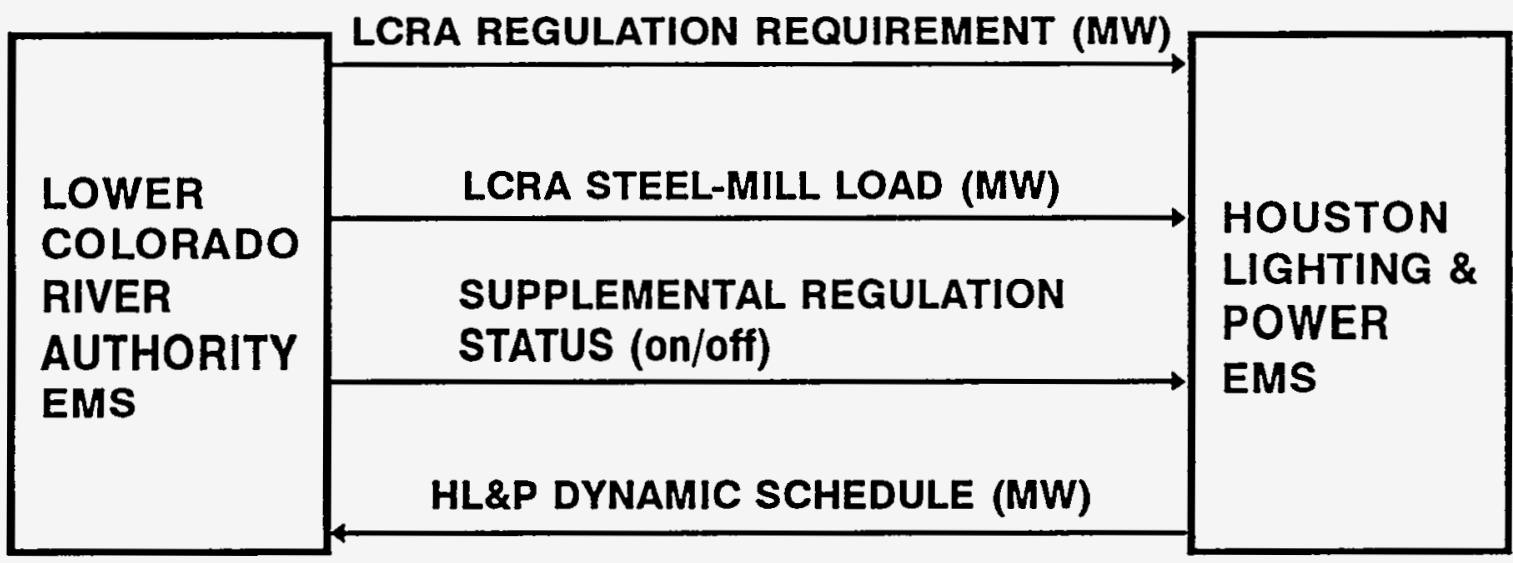

Fig. 4. Data flows between the Lower Colorado River Authority and Houston Lighting \& Power to implement the supplemental-regulation service provided by Houston. EMS is energy-management system. 
$\ldots$

$-3$

. 


\section{DYNAMIC-SCHEDULING COSTS}

Dynamic scheduling involves both initial and ongoing costs. Initial costs include those related to the purchase and installation of additional metering, telemetering, communications, and computing equipment. For example, utilities may need to obtain or upgrade communications systems, such as leased telephone lines, microwave systems, or fiber-opticcable systems. Similarly, energy-management systems in control centers may need to be expanded, involving both hardware and software. In other cases where data are already being collected and telemetered to one control center, initial investments might be quite modest. The primary ongoing costs relate to communication systems (especially to lease telephone lines) and to periodic inspections, maintenance, and repair of field equipment.

Because these costs are so dependent on the specific circumstances, we were able to obtain only a few estimates of the initial and ongoing costs of DS (Table 8). On the basis of these estimates, we developed the analysis shown below. As a base case, we assume that the incremental initial cost of DS is $\$ 10,000$ per DS metering point and the ongoing costs are $\$ 2,000 /$ month. We normalize results in mills $/ \mathrm{kWh}$. Over time, as technologies advance and as DS is used more widely, these costs are likely to decline.

For a single metering point (e.g., the output of a single generator), the monthly payments, assuming that the capital costs are depreciated over 10 years at a $9 \%$ discount rate, are $\$ 2130$. For a $100-\mathrm{MW}$ generator with a load factor of $65 \%$, this $\$ 2130 /$ month is equivalent

Table 8. Estimates of the capital and ongoing costs of dynamic scheduling

Initial cost

$(\$ /$ schedule $)$
Ongoing cost

(\$/schedule-month)

\begin{tabular}{lrc}
\hline${\text { Houston Lighting \& } \text { Power }^{\mathrm{a}}}$ & \\
Marginal & 3,700 & 700 \\
Embedded & 7,200 & $8,700^{\mathrm{b}}$ \\
Wisconsin Public Power Inc. System $^{\mathrm{c}}$ & 20,400 & 2,200 \\
\hline
\end{tabular}

Sources: Bobo (1996) and Steitz (1996).

${ }^{a}$ The HL\&P estimates include no costs for computer hardware and software or for the real-time metering costs that the dynamically scheduled load or generation might face.

${ }^{b}$ The HL\&P estimate of ongoing embedded costs is quite high because the HL\&P system has additional capacity that could be used to support more dynamic schedules.

${ }^{c}$ The Wisconsin estimates involve communications among three control centers. 
to $0.045 \mathrm{mills} / \mathrm{kWh}$. Compared to spot prices (which are roughly $25 \mathrm{mills} / \mathrm{kWh}$ ), DS is very cheap-well under $1 \%$ of the cost of power.

If DS involves the use of another utility's transmission system (as it often does) and if that utility charges for transmission service and losses, then the cost increases dramatically." Assume that this dynamic scheduling of a 100-MW generator involves a transmission charge of $\$ 1.5 / \mathrm{kW}$-month and losses of $3 \%$ charged at an average price of 25 mills $/ \mathrm{kWh}$. Now the cost increases from 0.045 to 3.96 mills $/ \mathrm{kWh}(0.045$ for $\mathrm{DS}+3.16$ for transmission +0.75 for losses). Normalized by demand, the cost increases from $\$ 0.021 / \mathrm{kW}$-month to $\$ 1.88 / \mathrm{kW}$-month. These results suggest that the costs of DS itself might be a very small percentage (about $1 \%$ in this example) of the costs of transmission and losses.

Figure 5 expands the example given above to show how the costs of DS and the costs of DS plus transmission plus losses vary with the size of the load or generation and with the number of metering points for loads. The DS costs alone drop rapidly as the size of the load or generation increases. However, the costs of transmission and losses increase linearly with load.

$\operatorname{cosT}(\$ / M W h)$

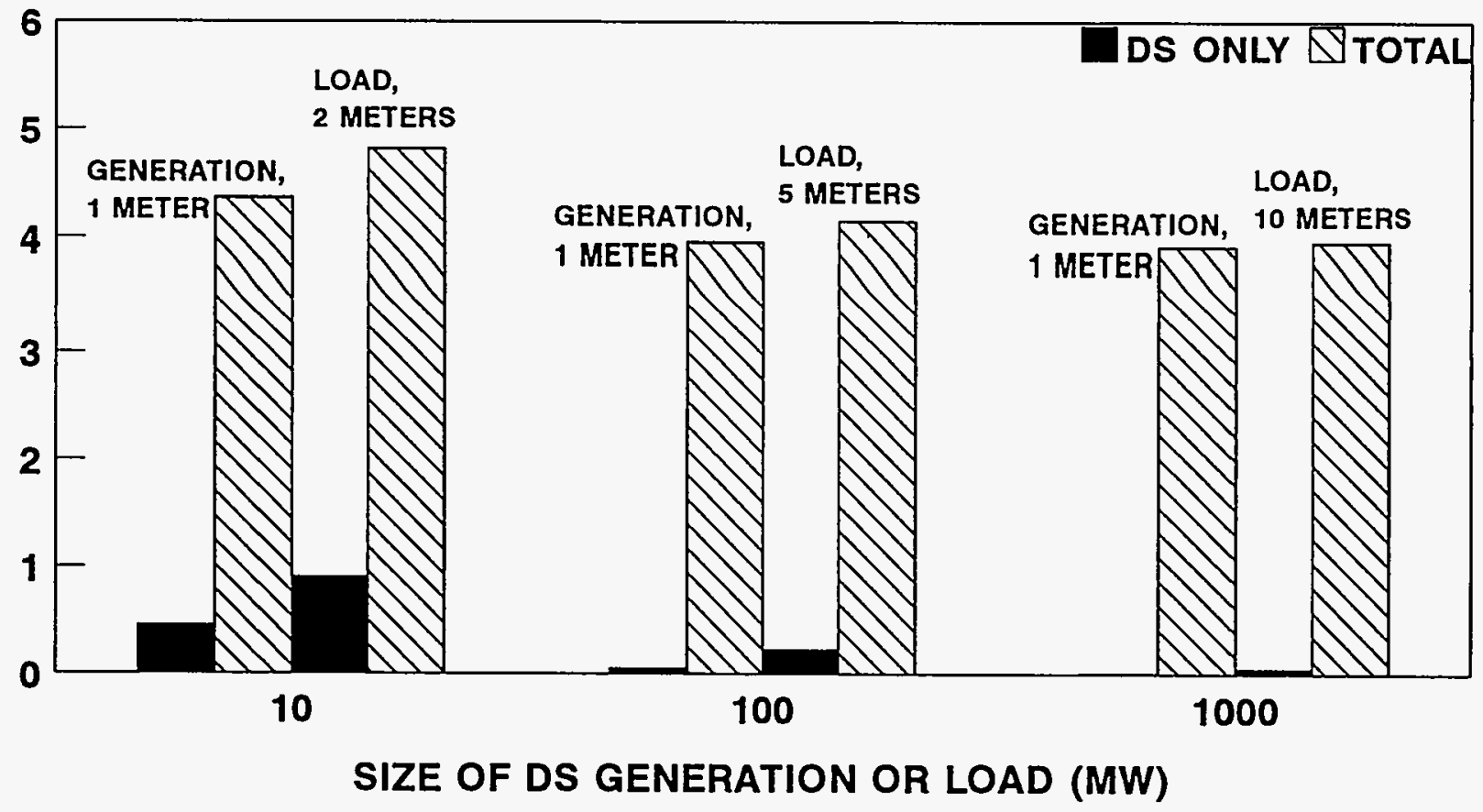

Fig. 5. Estimated costs of dynamic scheduling and of dynamic scheduling plus transmission and losses. These results assume that initial and ongoing costs of dynamic scheduling are $\$ 10,000 /$ point and $\$ 2000$ /point-month, transmission costs $\$ 1.5 / \mathrm{kW}$-month, and losses cost $\$ 0.75 / \mathrm{MWh}$ (3\% losses at $\$ 25 / \mathrm{MWh}$ ).

*Inclusion of transmission costs and losses assumes that DS is compared to a reference in which electric service is provided from within the physical-host control area. If, however, the reference is a static schedule, then there may be little or no incremental transmission costs or losses associated with DS. 


\section{RELATIONSHIP TO ANCILLARY AND OTHER GRID SERVICES}

An important issue related to dynamic scheduling concerns what functions can reasonably be moved from one control area to another. Consider real and reactive power as examples of the two ends of the spectrum. The typical primary purpose of DS is the movement of real power. On the other hand, electrical engineers and system operators know well that reactive power cannot be moved long distances because the physical losses are too high (as much as 10 to 20 times that for real power). This suggests that a generator located in one control area cannot provide voltage support to another, distant control area or even to distant locations within its physical-host control area.

\section{ANCILLARY SERVICES}

Table 9 summarizes our current views on the relationship between DS of generation and the provision of ancillary services. Scheduling, system control, and dispatch must involve both the physical- and electronic-host control areas. Intervening control areas, through which the power flows, need to be informed of the scheduled transfers and may need to receive the dynamic schedules for their own use (e.g., calculation of available transmission capability and of losses). The use of dynamic, rather than static, scheduling may relieve system operators of certain tasks that they otherwise would have to perform (such as maintaining frequent telephone contact to manually update schedules).

As noted above, voltage support most likely must remain with the physical host. Similarly, the ability of a generator to restart itself without obtaining electricity from the grid (black-start capability) will be most valuable to the physical-host control area in its restoration plan. The same holds true for network stability services, such as the use of power-system stabilizers at certain generating stations. Thus, these services will likely not be transferred from the physical-host control area.

The various real-power generation services, including regulation, frequency response, spinning reserve, supplemental reserve, and interhour load following, can all be electronically transferred. However, the transfer may be subject to transmission constraints, under both expected congestion and emergency conditions (such as the failure of a major transmission

NERC (1995) notes that "control areas that use dynamic scheduling or pseudo-ties for jointly owned units must reflect their respective share of the unit governor droop response into their respective frequency bias settings." In other words, the two control areas share the unit's frequency response in the same proportions that they share the unit's output. 
line). Dynamically scheduling spinning and supplemental reserves is, in our view, problematic because these reserves are intended to protect against both generation contingencies (no problem here) and transmission contingencies (possible problems here).

DS is likely to increase losses, and these losses must be recognized by both control areas, as well as intervening control areas, by providing additional capacity to make up these losses. That is, one or more entities will have to pay for, in either dollars or power, these incremental losses. Prowse et al. (1994) suggest that for dynamic scheduling of regulation, in which the hourly integral of power flows is near zero (i.e., no energy is transferred from one control area to another), the importance of transmission losses is reduced. This point may be valid with respect to energy losses for some types of DS but not for demand (capacity) losses, as noted by McReynolds (1996). (The nonlinearities associated with the $i^{2} R$ characteristic of losses may yield positive losses even when there is no net energy transfer.)

Table 9. Generator provision of ancillary services when dynamically scheduled

\begin{tabular}{|c|c|}
\hline Ancillary service & $\begin{array}{l}\text { Disposition between physical- } \\
\text { and electronic-host control areas }\end{array}$ \\
\hline $\begin{array}{l}\text { Scheduling, system control, and } \\
\text { dispatch }\end{array}$ & $\begin{array}{l}\text { Scheduling (automated rather than manual) involves } \\
\text { both control areas; dispatch is transferred from } \\
\text { physical to electronic host }\end{array}$ \\
\hline $\begin{array}{l}\text { Reactive supply and voltage } \\
\text { control from generation sources }\end{array}$ & $\begin{array}{l}\text { Stays with physical host, high losses may prevent } \\
\text { transfer to electronic host }\end{array}$ \\
\hline Regulation & \multirow{4}{*}{ Can be moved to electronic host } \\
\hline Frequency response & \\
\hline Interhour load following & \\
\hline Energy imbalance & \\
\hline Spinning reserve & \multirow{2}{*}{$\begin{array}{l}\text { Can be moved to electronic host, subject to } \\
\text { transmission constraints and congestion limits }\end{array}$} \\
\hline Supplemental reserve & \\
\hline Losses & $\begin{array}{l}\text { Higher losses because generation output moved to a } \\
\text { more distant control area, can be provided by either } \\
\text { control area }\end{array}$ \\
\hline Backup supply & $\begin{array}{l}\text { Can be provided in electronic-host control area, } \\
\text { subject to transmission constraints and congestion } \\
\text { limits }\end{array}$ \\
\hline Restoration (black start) & Most valuable in physical-host control area \\
\hline
\end{tabular}


The treatment of ancillary services for dynamically scheduled loads is analogous to that for generators (Table 10). The network services related to voltage support, system restoration, and network stability will all likely be obtained from the physical-host control area rather than from a remote control area.

On the other hand, real power, regulation, interhour load following, energy imbalance, and loss replacement can all be provided by the electronic host. As discussed above, the reserve services can probably be provided by the electronic host, subject to the availability of sufficient transmission capacity. Losses can be handled either through the provision of extra energy or the payment of money. The Orlando Utilities Commission dynamically schedules loads across the transmission systems of Florida Power \& Light and Florida Power Corp. It compensates Florida Power \& Light for the losses on that system with money, and it compensates Florida Power Corp. for its losses with energy; in both cases, the loss factor is an assumed constant.

Table 10. Treatment of ancillary services when a load is dynamically scheduled

\begin{tabular}{|c|c|}
\hline Ancillary service & $\begin{array}{l}\text { Disposition between physical- } \\
\text { and electronic-host control areas }\end{array}$ \\
\hline $\begin{array}{l}\text { Scheduling, system control, } \\
\text { and dispatch }\end{array}$ & $\begin{array}{l}\text { Scheduling (automated rather than manual) involves } \\
\text { both control areas; control (e.g., load shedding) is } \\
\text { transferred from physical to electronic host }\end{array}$ \\
\hline $\begin{array}{l}\text { Reactive supply and voltage } \\
\text { control from generation sources }\end{array}$ & $\begin{array}{l}\text { Obtained from physical host because high losses may } \\
\text { prevent transfer from electronic host }\end{array}$ \\
\hline Regulation & Provided by electronic host \\
\hline Frequency response & Not relevant to individual loads \\
\hline $\begin{array}{l}\text { Interhour load following } \\
\text { Energy imbalance }\end{array}$ & Provided by electronic host \\
\hline Spinning reserve & Provided by electronic host, subject to transmission \\
\hline Supplemental reserve & constraints and congestion limits \\
\hline Losses & $\begin{array}{l}\text { Higher losses because generation to serve the load } \\
\text { comes from a more distant control area, can be } \\
\text { provided by either control area }\end{array}$ \\
\hline Backup supply & $\begin{array}{l}\text { Can be provided by electronic-host control area, subject } \\
\text { to transmission constraints and congestion limits }\end{array}$ \\
\hline Restoration (black start) & Not relevant to individual loads \\
\hline
\end{tabular}




\section{GRID FUNCTIONS}

As noted above, DS likely involves the use of additional transmission. For the case shown in Fig. 1, electronically moving $\mathrm{Ll}$ from $\mathrm{A}$ to $\mathrm{C}$ would likely increase transmission flows in all three control areas, $\mathrm{A}, \mathrm{B}$, and $\mathrm{C}$. If the electronic transfer involves regulation (i.e., the minute-to-minute fluctuations in load and the generator response to those fluctuations), then extra transmission capacity might need to be reserved. McReynolds (1996) notes that certain transmission lines in the Pacific Northwest have dynamic limits that can be reached within one minute and thermal limits that can be reached within five minutes. He cites a nominal 400-MW load that has 1-minute fluctuations of $\pm 10 \mathrm{MW}$.

McReynolds proposes the following method to determine the amount of transmission capacity needed, beyond that reserved for the average hourly flow. First, decompose the load into its slowly varying (interhour load-following) and fluctuating (regulation) components with the moving average of 1 -minute loads. The differences between the actual load and the moving average are the short-term fluctuations of interest here. Calculate the absolute values of these fluctuations and reserve three times the standard deviation of these fluctuations for this extra transmission. McReynolds' analysis of 1 hour of 1-minute moving-average data for a 270-MW load shows a mean of the absolute deviations of $1.7 \mathrm{MW}$ and a standard deviation of $1.3 \mathrm{MW}$. These numbers imply a need to reserve an extra $5.6 \mathrm{MW}(1.7+3 \times 1.3=5.6)$ of transmission capacity beyond the $270 \mathrm{MW}$ implied by the mean load. If a 5-minute moving average had been used instead of a 1-minute average, the extra transmission requirement would have been 3.5 $\mathrm{MW}$ instead of $5.6 \mathrm{MW}$.

Transmission constraints can limit the amount of power that is dynamically scheduled. Some constraints are binding for only a few hours a year, while others might be important for a substantial fraction of the time. And many constraints might be imposed by control centers for reliability reasons to prevent problems that might arise if certain contingencies (e.g., another transmission line tripping offline) occur. These limits on DS, however, are conceptually no different from those that occur with static scheduling.

The control centers involved with DS must have procedures in place to handle the inevitable, even if rare, failures of metering, telemetry, or computer equipment. During such times, one or both control centers will not know what the time-varying output of the generator (or the time-varying demand of the load) is. Typically, the procedure calls for use of the most recent reading or of the use of the signal from the same hour during the preceding day or the reversion to a static schedule. In most cases, such failures require telephone communication between the two control centers to ensure that their actions are consistent with each other and will not impair interconnection reliability. Almost all the people we spoke with believed that failures of DS systems are no more frequent and no more difficult to manage than those associated with the failures of other bulk-power metering and communication systems. HL\&P has programmed its EMS so that, when DS communications fail, the system "locks in" the last valid value of the load or generation being dynamically scheduled. The EMS then rings an 
alarm to notify the system operators of the situation so that they can telephone the other control center and decide manually what to do.

Incentives or performance standards should be in place to encourage DS users (both generators and loads) to maintain their meters and telemetry equipment in good condition and to repair outages promptly. One way to encourage such behavior is to have the default control area (the physical host) impose a penalty ${ }^{*}$ or allow various suppliers to sell backup service (e.g., regulation) at a competitive rate whenever such failures occur. The use of market-based rates, where feasible, will encourage DS users to make the appropriate tradeoffs between equipment maintenance and purchase of supplemental services.

Similarly, procedures must be in place when transmission or generation contingencies occur. For example, if the interconnection breaks up into islands and the physical- and electronic-host control areas are in different islands, the DS schedule needs to be interrupted. Absent communication among the control-center operators, the electronic signal might still be operational even though the transmission link was interrupted. In the case of the Colstrip units mentioned above (Table 6), the Montana Power Company control center is responsible for monitoring actual tieline flows, noting when they fall to zero and then notifying the other control centers when islanding occurs. Failure to interrupt the DS signals would lead to overgeneration (and a too high frequency) in the island that contains the generator's physical host and would lead to undergeneration in the island(s) that contain the generator's electronic host(s).

Finally, the physical and electronic host control areas need to agree on accounting procedures, primarily to reconcile the errors in the DS meters to the revenue meters. This type of problem occurs in many interutility situations, and DS appears to pose no new difficulties.

${ }^{*} \mathrm{HL} \& \mathrm{P}$ imposes a charge of $10 \notin / \mathrm{kWh}$ for imbalances in either direction as a way to encourage reliable and accurate customer operation of DS equipment. 


\section{NEED FOR ADDITIONAL WORK}

Although we obtained a wealth of information on dynamic scheduling, primarily from our interviews, several key issues require additional analysis.

Transmission requirements: As McReynolds (1996) notes, dynamically scheduling generation or load that includes minute-to-minute fluctuations (i.e., regulation) may impose additional burdens on the transmission network beyond those that would be associated with a statically scheduled load. How should these fluctuations be treated in assigning transmission capacity to the dynamically scheduled load or generation? Transmission capacity will vary depending on ambient temperatures, wind speeds, and other factors and will differ between continuous and emergency conditions. One also has to be careful not to double-count uncorrelated fluctuations from individual loads or generators. That is, the transmission provider should be allowed to charge for the net aggregation of the dynamically varying loads or generation outputs, not for the sum of the individual values.

- Distance limits: What, if any, problems might arise as dynamic schedules traverse greater distances and more control areas? Will the coordination of schedules, detection and treatment of loop flows, and calculation of losses create problems?

Costs: What are the incremental initial (capital) and operating costs of DS? How do they vary with the size of the generation or load being scheduled? How are these costs affected by the accuracy and reliability of the equipment chosen? How do these costs compare with those for transmission services and for transmission-system losses? What is the potential for the costs of metering and telemetry to decline during the next few years?

- Exclusion of certain types of load and generation: Are there certain loads (e.g., electricarc-furnace steel mills) that should not be dynamically scheduled? If so, what are the defining characteristics of such loads (e.g., the ratio of standard deviation to mean value of load, maximum ramp rate in $\mathrm{MW} /$ minute, or frequency of sign changes during an hour)? Would such criteria be a function of the size of the load (e.g., tighter limits on larger than on smaller loads)? Do comparable constraints apply to certain types of generation?

- Protocols to deal with equipment failures: What a priori procedures should be established for metering and communication failures (e.g., manual scheduling using the 
last hour's value or the last actual value of load or generation)? What financial arrangements are appropriate for different protocols (i.e., how is risk to be shared between the physical and electronic hosts)? Are these protocols likely to differ materially from those used to deal with other metering and communication contingencies? Should these protocols vary with the size of DS load or generation?

Effects of DS on compliance with NERC control performance criteria: What data should the physical- and electronic-host control areas collect (e.g., on pre- and post-DS ACE and compliance with the NERC A1 and A2 criteria) to determine what effects, if any, DS has on control-area performance? What frequency, accuracy, and redundancy requirements are needed to assure sufficiently high-quality data for such analyses? What data should be collected to assess the effects of DS on inadvertent interchange accounts?

Control-center requirements: What problems might arise as the number of dynamic schedules increases? When a physical or electronic host is involved with multiple dynamic schedules, can these schedules be dynamically aggregated (e.g., by the control center's energy-management system) before use by the control center's AGC system?

Limits on number of DS schedules: Are there computing, transmission, and personnel limits (e.g., costs and complexity) on the number of dynamic schedules that a control center can handle? If so, what are the determinants of these limits, and what costs do they impose? Do reliability considerations impose additional limits?

- Stability limits: In regions that are vulnerable to stability problems, could DS aggravate such problems? Should DS be restricted across sensitive or constrained interfaces?

Relationship between ancillary services and DS: Which services from a dynamically scheduled generator can be electronically transferred, and which services must remain with the physical-host control area? Similarly, for dynamically scheduled loads, which ancillary services can be provided remotely by the electronic host, and which would have to remain with the physical-host control area? 


\section{CONCLUSIONS}

The many examples discussed above demonstrate that dynamic scheduling is a reality in today's electricity industry, that it has been used by many utilities for at least two decades, and that it works. One system operator at the receiving end of a dynamically scheduled generator said that DS operates "as if it was in our backyard."

The NERC Interconnected Operations Services Working Group (1996) developed templates to summarize the key features of each of the 13 services it defined. Table 11 is a slightly modified version of its DS template.

In summarizing the findings of this study, we return to the issues listed in Chapter 1 . We found two essentially equivalent definitions of DS. The definitions differed only in the term in the ACE equation modified to reflect DS. We did, however, find many different kinds of DS applications for both loads and generation.

We also uncovered a range in the size of loads and generation that is dynamically scheduled. Generally speaking, the generation applications are for larger sizes than are the load applications. Several of the generation applications involved more than $1000 \mathrm{MW}$, whereas many of the load applications were under $100 \mathrm{MW}$. The number of points from which data need to be collected and telemetered may be more important, especially from a cost standpoint, than the size of the load or generation. The loads typically involved several metering points, whereas the generation examples generally involved only one point, the generating station itself.

None of our survey respondents offered clear rules concerning the maximum distance over or the maximum number of control areas through which DS could be conducted. Our cost analysis, however, suggests that the costs of transmission service and of loss replacement dominate the direct costs of DS. The need to compensate multiple control areas for transmission and losses would limit such applications of DS, as well as static scheduling.

Typically, DS data are telemetered at the same rate as that used in the control area's AGC system, once every two or four seconds. We learned of no special problems associated with the accuracy and reliability of the meters and telemetry equipment used for DS. Indeed, most respondents indicated that problems associated with accuracy and reliability were no different from those associated with other systems for data collection and transmission, such as those used to record and transmit tieline flows and voltages to the control center. In a similar fashion, the control centers have prepared contingency plans that specify the actions to take when DS equipment fails. 


\section{Table 11. NERC Interconnected Operations Services Working Group draft template for dynamic scheduling}

\begin{tabular}{|c|c|}
\hline Definition & $\begin{array}{l}\text { The service that provides for the real-time metering, telemetry, computer software and } \\
\text { hardware, communications, engineering, and administration required to electronically move } \\
\text { a portion or all of the "watt-type" services associated with generation or load out of the } \\
\text { control area to which it is physically connected and into a different control area. This is not } \\
\text { a service to match load and generation within a control area. }\end{array}$ \\
\hline $\begin{array}{l}\text { Required for } \\
\text { system } \\
\text { security or to } \\
\text { equitably } \\
\text { allocate costs? }\end{array}$ & $\begin{array}{l}\text { No. However, it provides the transmission customer the option of obtaining regulation } \\
\text { service from an entity outside the control area, integrating its loads and resources located } \\
\text { in different control areas, and moving load and generation entirely to another control area. }\end{array}$ \\
\hline \multicolumn{2}{|l|}{ Technical issues: } \\
\hline Requirements & $\begin{array}{l}\text { The monitoring and telemetry must be compatible with the sending and receiving control } \\
\text { areas' AGC algorithms, telemetering equipment, communication protocols, and scan rates. }\end{array}$ \\
\hline Time frame & $\begin{array}{l}\text { The service must be provided continuously. The telemetering scan rate is typically } 2 \text { to } 4 \\
\text { seconds. }\end{array}$ \\
\hline Measurement & $\begin{array}{l}\text { Telemetering calibration and equipment and communication reliability are measures of the } \\
\text { effectiveness of this technology. Audit rights are needed to ensure the accuracy of the } \\
\text { metering and telemetering equipment. }\end{array}$ \\
\hline $\begin{array}{l}\text { Self- } \\
\text { provision }\end{array}$ & $\begin{array}{l}\text { Service requires coordination between the transmission customer and the sending, } \\
\text { receiving, and any intermediate control areas. Metering and telemetering equipment can be } \\
\text { self-provided with the associated requirements for calibration and repair, but the service } \\
\text { itself can be provided only by the control areas. }\end{array}$ \\
\hline $\begin{array}{l}\text { Commercial } \\
\text { obligations }\end{array}$ & $\begin{array}{l}\text { Transmission providers are not required to offer dynamic scheduling in general, but they } \\
\text { must make a good-faith effort to do so. }\end{array}$ \\
\hline Comments & $\begin{array}{l}\text { 1. There is limited experience on the impact of large numbers of dynamic schedules on } \\
\text { control-area operations. } \\
\text { 2. Electronically moving generation or load from one control area to another can be } \\
\text { accomplished by modifying either the } \mathrm{I}_{\mathrm{A}} \text { or the } \mathrm{I}_{\mathrm{S}} \text { term in the } \mathrm{ACE} \text { equation. Modifying } \\
\text { the } \mathrm{I}_{\mathrm{A}} \text { term is not dynamic scheduling, but it has the same effect. } \\
\text { 3. The loss of telemetry or transmission creates a new default control area [the physical } \\
\text { host]. Procedures must be in place to assure continued service to the transmission } \\
\text { customer and proper compensation to the default control area. A simple approach would } \\
\text { treat differences between control areas as inadvertent interchange. This may be } \\
\text { acceptable if reciprocal arrangements prevail and disruptions are rare. Otherwise, } \\
\text { contractual arrangements are needed to recognize and compensate for the service } \\
\text { provided. } \\
\text { 4. When telemetry is lost, a procedure to freeze telemetry at all affected control areas must } \\
\text { be implemented. Chronic failures suggest that alternate telemetry should be installed. } \\
\text { 5. Transmission capacity may need to be reserved for this service, in particular for } \\
\text { regulation service. }\end{array}$ \\
\hline Future work & $\begin{array}{l}\text { 1. Are there any types of loads that should not be dynamically scheduled (e.g., highly } \\
\text { volatile loads)? } \\
\text { 2. What impact does distance or number of control areas have on the ability to provide } \\
\text { or deliver dynamically scheduled services? }\end{array}$ \\
\hline
\end{tabular}

Source: Adapted from NERC Interconnected Services Working Group (1996). 
Several people mentioned the likelihood that DS could lower the costs of system control and operation and reduce errors because the process is largely automated and involves less human interaction than does static scheduling. On the other hand, DS could require larger, faster computers to handle the additional, time-varying transactions.

The costs of DS appears to be quite low relative to both the cost of power and to the costs of transmission and transmission losses. In addition, the many applications of DS presented in Chapter 4 suggest its cost-effectiveness.

Although our findings are generally quite positive about dynamic scheduling, we need to be cautious about its widespread use, given its likely increase in the complexity of controlarea operations and its possible adverse effects on reliability. We should be mindful of the cautions raised by Falcone (1991) concerning metering complexity, metering and telemetry failures, metering and computing errors, and possible confusion during emergency conditions over which entities are responsible for meeting which loads. These concerns, however, need not limit the cooperative and coordinated expansion of DS.

In conclusion, the number and complexity of dynamic-scheduling transactions are likely to increase in the future as generation becomes more competitive, open access of transmission networks becomes a reality, pancaking of transmission rates is reduced through the creation of independent system operators, and market participants (customers, suppliers, marketers and brokers, and others) seek more choices.

\section{ACKNOWLEDGMENTS}

We thank Detroit Edison and the U.S. Department of Energy for their financial support of this project. The conclusions presented here, however, are our own and do not necessarily represent the views of either sponsor. We thank Antonio Sammut and Charles Smith for their continuing guidance and support throughout this project. We thank Donald Benjamin, Malcolm Bertsch, Patrick Bourne, Terry Bradshaw, Paul Cafone, Walter Campbell, Gerry Cauley, John Dake, James Dyer, Victor Elmer, Dennis Eyre, Charles Falcone, Robert Fountain, William Gaines, Erv Hedegaard, Ali Jamshidi, Richard Kafka, Larry Larson, Kenneth Laughlin, Warren McReynolds, Steven Naumann, Richard Polich, Gregory Ramon, Paul Shortley, Jerry Smith, Clyde Stansberry, Edward Stein, Peter Steitz, John Stout, David Sutherland, Ward Uggered, Keith Uelsmann, Raymond Vice, Steven Walton, and Thomas Washburn for participating in our telephone interviews. We thank Gregory Basheda, James Dyer, Victor Elmer, Ross McEacharn, Warren McReynolds, Charles Smith, Peter Steitz, John Stout, David Sutherland, Charles Vartanian, Raymond Vice, and Steven Walton for their helpful comments on a draft of this report. We thank Fred O'Hara for editing this report and Ethel Schorn for managing its clearance, printing, and distribution. 


\section{REFERENCES}

American Municipal Power-Ohio, Inc. 1996, Request for Clarification and Rehearing of American Municipal Power-Ohio, Inc., Docket Nos. RM95-8-000 and RM94-7-001, before the Federal Energy Regulatory Commission, Westerville, OH, May 24.

D. R. Bobo 1996, "Transmission Cost of Service Rate Filing Workpapers," Docket No. 15639, before the Texas Public Utility Commission, Houston Lighting \& Power, Houston, TX, May 2.

Electric Reliability Council of Texas 1995, Operating Guides, Austin, TX, June.

V. Elmer 1996, personal communication, Operations Department, Cajun Electric Power Cooperative, New Roads, LA, October.

C. A. Falcone 1991, "The Questionable Practice of 'Dynamic Scheduling," Proceedings of the American Power Conference, 918-923, Chicago, IL, April.

E. Hirst and B. Kirby 1996, Ancillary-Service Details: Regulation, Load Following, and Generator Response, ORNL/CON-433, Oak Ridge National Laboratory, Oak Ridge, TN, September.

W. L. McReynolds 1996, personal communication, Bonneville Power Administration, Vancouver, WA, October 3.

D. D. Might, S. W. Mays, B. Billiter, R. C. Jenkins, J. L. Steck, N. O. Woody, and J. T. Eisenhauer 1978, "An Algorithm for Multi-Company Regulating Control of Commonly Owned Generating Units," IEEE Conference on Control of Power Systems, Oklahoma City, OK, March.

North American Electric Reliability Council 1995, NERC Operating Manual, Princeton, NJ.

North American Electric Reliability Council Interconnected Operations Services Working Group 1996, Interconnected Operations (Ancillary) Services Workshop, Power Delivery Group, Electric Power Research Institute, Palo Alto, CA, October 22-23.

D. C. H. Prowse, P. Koskela, T. A. Grove, and L. R. Larson 1994, "Experience with Joint AGC Regulation," 94 WM 192-5PWRS, presented at the 1994 Winter meeting of the IEEE Power Engineering Society, Institute of Electrical and Electronic Engineers, Piscataway, NJ, January. 
P. Steitz 1996, personal communication, Wisconsin Public Power Inc. System, Sun Prairie, WI, December.

F. Trefny, D. Sutherland, R. Thibeault, B. Tandy, and J. Chiao 1996, "Regulation Services Boost Control Performance," IEEE Computer Applications in Power, 29-32, January.

U.S. Federal Energy Regulatory Commission 1996, Promoting Wholesale Competition Through Open Access Non-Discriminatory Transmission Services by Public Utilities; Recovery of Stranded Costs by Public Utilities and Transmitting Utilities, Final Rule, Docket Nos. RM95-8000 and RM94-7-001, Order 888, Washington, DC, April 24. 


\section{INTERNAL DISTRIBUTION}

1. L. Baxter

2. V. D. Baxter

3. L. Berry

4. D. J. Bjornstad

5. M. A. Brown

6. J. Christian

7. G. Courville

8. T. R. Curlee

9. P. D. Fairchild

10. S. Hadley

11. L. J. Hill

12. E. Hirst

13. P. J. Hughes

14. B. Kirby

15. R. Lee
16. P. Leiby

17. J. M. MacDonald

18. V. C. Mei

19. D. E. Reichle

20. A. C. Schaffhauser

21. M. Schweitzer

22. R. B. Shelton

23. J. Tomlinson

24. B. E. Tonn

25. J. Van Dyke

26. J. VanCoevering

27. T. J. Wilbanks

28. Central Research Office

29. Document Reference Section

30. Laboratory Records (RC)

\section{EXTERNAL DISTRIBUTION}

31. Dr. Lilia A. Abron, President, PEER Consultants, P.C., 1000 N. Ashley Drive, Suite 312, Tampa, FL 33602

32. Dr. Thomas E. Drabek, Professor, Department of Sociology, University of Denver, Denver, CO 80208-0209

33. Dr. Stephen G. Hildebrand, Director, Environmental Sciences Division, Oak Ridge National Laboratory, P.O. Box 2008, Oak Ridge, TN 37831-6037

34. Dr. Susan F. Tierney, The Economic Resource Group, Inc., One Mifflin Place, Cambridge, MA 02138

35. Dr. C. Michael Walton, Ernest H. Cockrell Centennial Chair in Engineering and Chairman, Department of Civil Engineering, University of Texas at Austin, Austin, TX 78712-1076

36.-37. OSTI, U.S. Department of Energy, P.O. Box 62, Oak Ridge, TN 37831

38. Office of Assistant Manager for Energy Research and Development, DOE/ORO, P.O. Box 2001, Oak Ridge, TN 37831-8600

39.-750 External Electric Industry Policy Studies group distribution mailing list and extra copies to E. M. Schorn, 4500N, H-19A 